\author{
Wiesław Alejziak \\ https://orcid.org/0000-0002-0604-7577 \\ Akademia Wychowania Fizycznego w Krakowie \\ Wydział Turystyki i Rekreacji \\ Zakład Ekonomii i Zarządzania \\ wieslaw.alejziak@awf.krakow.pl
}

\title{
WYJAŚNIANIE NAUKOWE I ROZUMIENIE A EPISTEMOLOGICZNE PROBLEMY BADAŃ NAD TURYSTYKA (ROZWAŻANIA NA KANWIE TEORII KURTA LEWINA I JOHNA TRIBE'A)
}

\begin{abstract}
Abstrakt: W artykule scharakteryzowano istotę oraz różne modele wyjaśniania naukowego i eksplanacyjne walory rozumienia, wskazując na ich użyteczność oraz ograniczenia w poznawaniu praw i mechanizmów rządzących turystyką. Szczególną uwagę zwrócono na epistemologiczny wymiar dorobku wyłaniającego się z dotychczasowych badań i studiów nad turystyką, starając się ukazać nowe kierunki badań w tym zakresie. W pracy odwołano się do dwóch modeli rozważań o epistemologicznych aspektach badań nad turystyką, w których centralne miejsce zajmuje kategoria prawdy o turystyce, a które przedstawione zostały w dwóch artykułach J. Tribe'a.
\end{abstract}

Słowa kluczowe: turystyka, badania nad turystyką, teoria, typologia, wyjaśnianie, rozumienie, predykcja, epistemologia.

\section{WSTĘP}

Jednym z fundamentów nauki jest założenie istnienia rozpoznawalnej regularności oraz swoistego porządku $\mathrm{w}$ świecie rzeczywistym, co pozwala na uporządkowanie $\mathrm{i}$ „ustrukturowanie" różnych obszarów rzeczywistości społecznej i gospodarczej (Frankfurt-Nachmias, Nachmias, 2001). Przyjęcie tego założenia sprawia, że - niezależnie od stopnia intensywności zmian dokonujących się na współczesnym rynku turystycznym - nauka próbuje wyjaśniać zachodzące na nim różnorodne zjawiska, procesy, zdarzenia itd. W przypadku tak wieloaspektowego i dynamicznego zjawiska jak turystyka nie jest to jednak łatwe, tym bardziej że badania nad turystyką - niezależnie od pewnego postępu, jaki dokonał się $\mathrm{w}$ tej dziedzinie w ostatnich latach (Alejziak, 2005; Butler, 2015; Butowski, 2014; Dann, Nash, Pearce, 1988; Jafari, 2001; Liburd, 2012; Oviedo-García, 2016; Ritchie, Burns, Palmer, 2005) - ciągle znajdują się w początkowym stadium rozwoju (Alejziak, 2008a; Ballantyne, Packer, Axelsen, 2009; Benckendorff, Zehrer, 2013; Pearce, Butler, 1993; Tribe, 1997, 2006, 2010). W kontekście oceny dorobku badawczego turystyki duże znaczenie ma także fakt, że stanowi ona obecnie przedmiot zainteresowania reprezentantów wielu dziedzin i dyscyplin nauki, a badania $\mathrm{w}$ tym zakresie prowadzone są z różnych podejść i perspektyw metodologicznych (Alejziak, 2008b; Hall, Williams, Lew, 2004; Theuns, 1986; Winiarski, 2003, 2004;
Xiao, Smith, 2004). Ma to silne odzwierciedlenie m.in. w różnorodności wykorzystywanych typów wyjaśniania naukowego oraz specyfice realizacji innych funkcji nauki, jakimi są rozumienie oraz przewidywanie. $Z$ wymienionych powodów analiza i ocena dorobku wyłaniającego się z badań nad turystyką, zwłaszcza w perspektywie epistemologicznej, nie jest prosta.

Nauka - spełniając swoje trzy podstawowe funkcje: deskryptywną, eksplanacyjną i prognostyczną (Brzeziński, 2005) - ma na celu dostarczenie możliwej do jej zweryfikowania wiedzy, która pomaga wyjaśnić, przewidzieć i zrozumieć badane zjawiska empiryczne oraz cechy i/lub „zachowania obiektów” (tj. rzeczy, procesów, idei itd.), którymi zajmuje się dana dziedzina. W przypadku badań i studiów nad turystyką mamy do czynienia $\mathrm{z}$ wyjątkowo szerokim zestawem problemów i zagadnień badawczych, obejmujących zarówno sferę kultury (społeczeństwo, gospodarka), jak i natury (środowisko). Dla przedstawionych $w$ dalszej części pracy rozważań duże znaczenie ma także fakt, że wszystkie trzy wskazane funkcje nauki - chociaż charakterystyczne dla każdej z dziedzin i dyscyplin - realizowane są nieco inaczej na gruncie nauk przyrodniczych oraz społecznych i humanistycznych. Dotyczy to zwłaszcza wyjaśniania, któremu często przypisuje się funkcję nadrzędną ${ }^{1}$. 
Wyjaśnianie naukowe jest przedmiotem wielu dyskusji toczonych na gruncie różnych dyscyplin nauki. Jednym z ważnych problemów (zwłaszcza w wymiarze epistemologicznym) jest np. to, czy w eksplanacji bardziej chodzi o „wyjaśnienie tego, co nieznane, przez to, co znane naocznie - jak to postulował np. Arystoteles, czy też o wyjaśnienie tego, co naocznie znane, przez to co ukryte, nieznane, czyli o pogłębienie naszej wiedzy o świecie - jak to postulował K. Popper" (por. Bogucka, 1991, s. 96). W pewnym uproszczeniu można przyjąć, że wyjaśnianie $\mathrm{w}$ sensie naukowym polega na rozpatrywaniu i umiejscawianiu tego, co wyjaśniamy, w kontekście aktualnego stanu wiedzy oraz poszukiwaniu dla danego obiektu, faktu czy prawidłowości, odpowiedniego miejsca wśród zagadnień i wyjaśnień wcześniej już znanych i zaakceptowanych przez naukę. W przypadku turystyki - z uwagi na to, że badania i wiedza naukowa na jej temat ciągle są na początkowym etapie rozwoju, a dotyczące jej teorie mają wiele mankamentów - wyjaśnianie różnych zjawisk $\mathrm{z}$ nią związanych napotyka różne trudności. Jako przykład można wskazać teorie i wyjaśnienia dotyczące aktywności turystycznej, w tym zwłaszcza czynników tzw. ekskluzji turystycznej (inhibitorów tejże aktywności), które wyjaśniane są zwykle na gruncie teorii atrybucji, a nie wyjaśniania przyczynowego (Alejziak, 2016), z czego nawet badacze tego zjawiska nie zawsze zdają sobie sprawę. Ogólnie rzecz biorąc, w turystyce mamy stosunkowo niewiele dobrze ugruntowanych teorii (nie wspominając już o prawach), które mogłyby stanowić podstawę naukowego wyjaśniania i rozumienia zjawisk w niej zachodzących, przez co wyjaśnianie w dużym stopniu opiera się na typologizacji i prostym modelowaniu (Alejziak, 2013).

Istotę wyjaśniania naukowego często wiąże się z pojmowaniem eksplanacji, jako procesu mającego na celu udzielenie odpowiedzi na pytanie: „dlaczego?”2. Nie wdając się $\mathrm{w}$ tym momencie $\mathrm{w}$ dyskusję (toczoną, co warto podkreślić, na gruncie różnych dyscyplin nauki) na temat względności tego pytania, w niniejszym artykule skoncentrowano się na analizie różnych typów oraz roli wyjaśniania $\mathrm{w}$ badaniach i studiach nad turystyką, a także na epistemologicznych problemach wiedzy wynikającej z tych badań. Opisana problematyka wydaje się niezwykle istotna dla dalszego rozwoju tych badań oraz wiedzy o turystyce, zwłaszcza jeśli powiązać ją ze zmianami dokonującymi się w sferze tak pozyskiwania, jak i transferowania wiedzy.

\section{WYJAŚNIANIE JAKO FUNKCJA NAUKI - ISTOTA I RODZAJE WYJAŚNIANIA}

Wyjaśnianie naukowe można rozpatrywać w dwóch pespektywach, które wynikają z odmiennych tradycji, $\mathrm{w}$ jakich kwestie te rozstrzyga się na gruncie filozofii nauki, co syntetycznie ujęto w pracy Filozofia a nauka. Zarys encyklopedyczny (1987), w której czytamy:

\section{Z jednej strony wyjaśnić fakt to tyle, co wskazać regu- larność ogólną, której przypadkiem szczególnym jest ów fakt: „O fakcie jednostkowym mówimy, że jest wyja- śniony przez wskazanie jego przyczyny, a więc przez stwierdzenie, jakie jest prawo (lub prawa), których pew- nym przypadkiem szczególnym jest realizacja tego faktu (J.S. Mill)". Wedle drugiego ujęcia, wyjaśnić zjawisko to tyle, co wskazać prawo ujawniające jego istotę: zrozu- mieć zjawisko to tyle, co „wypowiedzieć jego istotę w for- mie pojęcia (G. Hegel)” (Filozofia a nauka..., 1987, s. 741).}

Pamiętać przy tym należy, że prawa nauki mogą odzwierciedlać substancjalne, atrybutowe, przyczynowo-skutkowe, funkcjonalne i strukturalne stosunki zależności badanych obiektów. Przyjmuje się więc, że taki charakter mogą mieć też wyjaśnienia ${ }^{3}$. W procesie wyjaśniania posługujemy się różnymi kategoriami, z których najważniejsze to: istota, prawo, przyczyna, funkcja i struktura (Nikitin, 1975). Czasami kategorie te traktowane są jako równoważne, jednak w rzeczywistości jest inaczej, np. gnoseologiczna teoria wyjaśniania zakłada, że ma ono złożoną strukturę, składającą się z hierarchicznie uporządkowanych poziomów. Na najwyższym mieści się kategoria „istota”, która pozwala odkryć i podać najogólniejszą charakterystykę natury wyjaśniania, na niższym - prawo, ujawniające zasadniczy mechanizm procedury wyjaśniania, natomiast na najniższym poziomie znajdują się takie kategorie, jak: przyczyna, funkcja, struktura itd., dostarczające konkretniejszej i bogatszej charakterystyki. Dopiero na ostatnim poziomie następuje przejście od ogólnej charakterystyki wyjaśniania do poznawania jego typów.

Klasyczny model wyjaśniania naukowego został zaproponowany przez Hempla i Oppenheima (1948, za: Nagel, 1985), którzy najpierw opracowali pierwotny schemat wyjaśniania dedukcyjno-nomologicznego (z gr. nomos - 'prawo' $)^{4}$, rozszerzony później o schemat wyjaśniania hipotetyczno-dedukcyjnego. $W$ modelu dedukcyjno-nomologicznym (D-N) zjawisko, które ma być wyjaśnione (oraz opisujące je zdanie), określane jest mianem eksplanandum (w jęz. łac. - 'to, co należy wyjaśnić'), zaś to, za pomocą czego wyjaśniamy nazywa się eksplanansem (w jęz. łac. - ‘wyjaśniający'). Każdy eksplanans składa się z dwóch metodologicznie różnych części: zdań reprezentujących fakty jednostkowe oraz zdań przedstawiających ogólne prawidłowości. Podstawę tego modelu wyjaśniania stanowi rozumowanie dedukcyjne, którego konkluzją jest zdanie-eksplanandum $E$, a układem przesłanek jest eksplanans, składający się z praw ogólnych $L_{1}, L_{2}, \ldots, L_{\mathrm{r}}$, i ze zdań $C_{1}, C_{2}, \ldots, C_{\mathrm{k}}$, stwierdzających pewne fakty szczegółowe, co przedstawia schemat ${ }^{5}$ :

$$
(D-N) \frac{\begin{array}{l}
L_{1}, L_{2}, \ldots, L_{\mathrm{r}} \\
C_{1}, C_{2}, \ldots, C_{\mathrm{r}}
\end{array}}{E} \begin{gathered}
\text { Eksplanans } \\
\text { Eksplanandum }
\end{gathered}
$$


Eksplanandum wyjaśniania jest zwykle zdaniem (lub układem zdań) opisującym wyjaśniany fakt (obiekt, układ, zjawisko, proces itd.), choć może też być generalizacją empiryczną, prawem czy teorią naukową. Eksplanans zaś składa się ze zbioru zdań wyjaśniających, które zawierają przynajmniej jedno prawo nauki (lub ich zbiór) oraz ze zdań stanowiących stwierdzenie pewnych faktów szczegółowych (warunki brzegowe). Za pomocą modelu dedukcyjno-nomologicznego możemy wyjaśniać - na podstawie badań oraz wynikającej z nich wiedzy - zarówno fakty jednostkowe (np. dlaczego $X$ częściej uprawia turystykę niż Y), jak też ogólne prawidłowości (np. dlaczego ludzie mieszkający w miastach są bardziej aktywni turystycznie od tych, którzy mieszkają na wsi).

Według Nikitina, z logicznego punktu widzenia można wskazać dwa podstawowe warunki dla explanandum oraz cztery dla explanansu. Explanandum winno stanowić ścisłe oraz dokładne odwzorowanie (w ujęciu językowym) przedmiotu wyjaśnianego i musi być prawdziwe. Natomiast explanans powinien odwzorowywać ten sam "obszar" przedmiotów co explanandum, zawierać co najmniej jedno prawo nauki, formułować warunki, przy których explanandum podpada pod prawo nauki, ponadto - biorąc pod uwagę zawartą $\mathrm{w}$ nim informację, nie może być tożsamy $\mathrm{z}$ explanandum, a także nie może zawierać go jako swej części (Nikitin, 1970, za: Lubański, 1972).

Należy podkreślić, że nie każdy rodzaj wyjaśniania jest wyjaśnianiem naukowym. Hempel i Oppenheim (1948) podali warunki, które powinno być spełnione, aby wyjaśnianie miało charakter naukowy: eksplanandum musi być konsekwencją logiczną eksplanansu, zdania tworzące eksplanans muszą być prawdziwe, zaś sam eksplanans musi zawierać przynajmniej jedno prawo ogólne oraz musi mieć treść empiryczną.

W literaturze dotyczącej metodologii nauki można znaleźć wiele typologii wyjaśniania oraz charakterystyk przydatności różnych jego typów dla poszczególnych dziedzin i dyscyplin nauki. Autor opracował je (tab. 1), częściowo wykorzystując podział i charakterystykę różnych rodzajów wyjaśniania, jaką przedstawili Waszczyk i Szczerbicki (2003), którzy zmodyfikowali wcześniejsze koncepcje Nikitina ${ }^{6}$.

Spośród wielu innych, wyodrębnianych w różnych klasyfikacjach typów, warto wspomnieć jeszcze o trzech rodzajach wyjaśniania: intencjonalnym, koegzystencjalnym oraz teoriologicznym.

Wyjaśnianie intencjonalne jest charakterystyczne dla nauk społecznych (głównie psychologii) i ujawnia ogromną złożoność międzyludzkich interakcji kulturowych i społecznych. Odwołuje się ono do zamierzeń (intencji, zamierzonych celów) działających ludzi, a więc $\mathrm{w}$ swojej istocie zbliżone jest do wyjaśniania teleologicznego; zawiera w sobie również pewne elementy wyjaśniania funkcjonalnego. Wyjaśnianie intencjonalne zasad- niczo polega na wskazaniu przyszłego stanu rzeczy, do którego wyjaśniane działanie miało doprowadzić, lecz ogólny schemat tego wyjaśniania powinien uwzględniać nie tylko czyjeś cele i pragnienia. Osoba działająca z pewną intencją wybiera bowiem określony sposób działania, ponieważ jest pewna, że to odpowiedni środek do celu. To przekonanie jest $\mathrm{z}$ kolei powiązane $\mathrm{z}$ innymi przeświadczeniami dotyczącymi aktualnego stanu rzeczy oraz związków przyczynowych pomiędzy środkami a celem. A zatem przy wyjaśnianiu intencjonalnym należy brać pod uwage relację między pragnieniami, przekonaniami i działaniem (Strawiński, 2011).

Wyjaśnianie koegzystencjonalne polega na odwoływaniu się do prawa wskazującego stałe związki między cechami wyjaśnianego obiektu, według formuły: „dla każdego $x$, jeśli $x$ ma cechę $W$, to $x$ ma cechę $Z "$. Według Waszczyka (który powołuje się m.in. na Bungego, Nikitina i Hajduka) w tym kontekście można przywołać takie rodzaje wyjaśniania, jak: strukturalne, substancjalno-atrybutywne oraz systemowe, albowiem „można przyjąć, z pewnym uproszczeniem, że wyżej wymienione rodzaje wyjaśniania, a także wyjaśnianie poprzez zaklasyfikowanie (taksonomiczne) oraz odwołanie się do innego poziomu zjawisk, korzystają z praw koegzystencjalnych i dlatego o każdym z nich można powiedzieć, że jest to wyjaśnianie koegzystencjalne" (Waszczyk, 1996, s. 148).

Z kolei w wyjaśnianiu teoriologicznym eksplanandum stanowi konkretna teoria, rozumiana jako strukturalnie zorganizowany system praw. $\mathrm{O}$ ile $\mathrm{w}$ innych typach wyjaśniania w eksplanansie występuje konkretne prawo (lub zbiór praw), a zakładana i związana z nim teoria często jest ukryta, o tyle w przypadku wyjaśniania teoriologiczego $\mathrm{w}$ eksplanansie musi zawierać się wyraźnie wskazana teoria wyjaśniająca eksplanandum ${ }^{7}$, niejako "podciągana" pod inną, bardziej znaną, ale przy pewnej jej modyfikacji (zmianie warunków brzegowych), co sprawia, że "coś mniej znanego" wyjaśnia się za pomocą „czegoś bardziej znanego".

Przy analizach funkcji, typów i zastosowań wyjaśniania naukowego należy mieć na uwadze to, że różne rodzaje wyjaśniania mogą się wzajemnie przenikać oraz łączyć ${ }^{8}$ i że niektóre mogą być tak formułowane (poprzez translację formuły praw jednego rodzaju na drugi), iż przybierają różną postać: kauzalną, koegzystencjalną, teleologiczną lub probabilistyczną. Trzeba jednak pamiętać o tym, że takie "przeformułowywanie" może być mylące, np. prawa funkcjonalne, mimo że można je ująć kauzalnie, to w swojej istocie takimi nie są, bo zwykle nie spełniają warunku asymetryczności; większość zależności funkcjonalnych ma bowiem charakter symetryczny i nie ulega zmianie, kiedy przyczynę i skutek "zamieni się miejscami” (Bunge, 1968, s. 375).

Warto też dodać, że nie każde wyjaśnienie naukowe oparte jest na tzw. prawdzie uniwersalnej (ogólnej), co ma szczególne znaczenie $\mathrm{w}$ przypadku rozważań czynionych na gruncie epistemologii. Dylematy związane 
Tabela 1. Podstawowe rodzaje wyjaśniania naukowego

\begin{tabular}{|c|c|c|}
\hline Lp. & $\begin{array}{c}\text { Wyjaśnianie } \\
\text { naukowe }\end{array}$ & Wyodrębnione ze względu na \\
\hline \multicolumn{3}{|r|}{ charakter praw stosowanych $\mathrm{w}$ eksplanansie } \\
\hline 1 & \begin{tabular}{|l|} 
Teleologiczne \\
(celowościowe)
\end{tabular} & $\begin{array}{l}\text { Polega na odwołaniu się do zasady, według której finalny stan danego zjawiska eksplanandum (np. zdarzenia) } \\
\text { wpływa w istotny sposób na stan wyjaśniany. Opiera się ono więc na poszukiwaniu celu, do jakiego zmierza lub } \\
\text { jakiemu służy określone zdarzenie. Podstawowe pytanie, które może być pomocne przy interpretacji teleologicz- } \\
\text { nej, brzmi: „po co?” (np. zaszło dane zdarzenie). W wyjaśnianiu teleologicznym poszukujemy więc „,czegoś" } \\
\text { (faktów, struktur, zdarzeń, okoliczności), czemu owo „,coś” służy lub będzie służyć w przyszłości. }\end{array}$ \\
\hline 2 & Funkcjonalne & $\begin{array}{l}\text { Opiera się na wskazaniu funkcji, jaką w danym układzie (np. gospodarce) pełni zjawisko eksplanandum (np. } \\
\text { rynek turystyczny). Wyjaśnienie to polega więc na powołaniu się na prawo, które pozwala stwierdzić określoną } \\
\text { zależność między elementem i układem. Z uwagi na to, że prawa funkcjonalne można klasyfikować jako } \\
\text { pewien rodzaj praw koegzystencjalnych, wyjaśnianie funkcjonalne często jest interpretowane jako wyjaśnianie } \\
\text { substancjalno-atrybutywne bądź systemowe. Niektórzy uważają też, iż jest ono pewną odmianą wyjaśniania } \\
\text { teleologicznego (twierdząc, że w istocie jest raczej opisem niż wyjaśnianiem). }\end{array}$ \\
\hline 3 & Genetyczne & $\begin{array}{l}\text { Polega na ustalaniu przemian, jakim podlega zjawisko eksplanandum w ciągu jakiegoś czasu. Jego ważną cechą } \\
\text { jest identyfikacja okoliczności, w jakich dochodzi do przekształcen, poprzez zbadanie czynników powodujących } \\
\text { zmiany. Wyjaśnić genezę czegoś, to znaczy odpowiedzieć na pytanie: „jak to powstało?” (ale także np. „,z czego"), } \\
\text { pamiętając o tym, że często okoliczności i przyczyny nie oddziałują natychmiast i bezpośrednio, a ich następ- } \\
\text { stwem są skutki odległe w czasie. Dlatego też pod uwagę bierze się głównie te czynniki, które wykazują } \\
\text { z wyjaśnianym zjawiskiem jakąś łączność substancjalną lub strukturalną. Niektórzy twierdzą, że wyjaśnianie } \\
\text { genetyczne (historyczne) jest odmianą wyjaśniania kauzalnego. }\end{array}$ \\
\hline 4 & $\begin{array}{l}\text { Kauzalne (przy- } \\
\text { czynowe) }\end{array}$ & $\begin{array}{l}\text { Odwołuje się do takich praw, które w ogólnym sformułowaniu można uznać za zgodne z zasadą: „takie same } \\
\text { przyczyny w takich samych warunkach wywołują takie same skutki”. W wyjaśnianiu tym często określa się } \\
\text { cały szereg etapów pośrednich, przez który przeszedł układ, zanim osiągną stan wyjaśniany. Pewną odmianą } \\
\text { wyjaśniania kazualnego jest tzw. wyjaśnianie skutkowe, które nazwane jest odwróconym wyjaśnianiem } \\
\text { przyczynowym. Podczas gdy wyjaśnianie przyczynowe odkrywa istotę jako coś pasywnego (przez coś wy- } \\
\text { tworzonego), to wyjaśnianie skutkowe pokazuje ją jako początek aktywny (sprawczy). W wyjaśnianiu przyczyno- } \\
\text { wym istota tego, co wyjaśniane, występuje jako skutek, a w wyjaśnianiu skutkowym - jako działająca przyczyna. } \\
\text { Wyjaśnianie skutkowe nie jest jednorodne, a jego skuteczność zależy od tego, jak dalece wytwarzane przez } \\
\text { obiekt skutki są stałe. }\end{array}$ \\
\hline 5 & Probabilistyczne & $\begin{array}{l}\text { W tym wyjaśnianiu zjawisko eksplanandum jest tłumaczone przez odwołanie się do prawa statystycznego, } \\
\text { czyli takiego, które - na podstawie rozkładu zmiennych w badanej próbie - pozwala ekstrapolować wyniki } \\
\text { na całą populację. Pomimo krytyki jest to w tej chwili najbardziej rozpowszechniony w naukach społecznych } \\
\text { (w tym zwłaszcza w ekonomii) typ wyjaśniania. Jeśli przyjąć ścisły determinizm, prawa statystyczne są formuło- } \\
\text { wane tylko z tego powodu, że nie można poznać wszystkich czynników zajścia danego zdarzenia. W kontek- } \\
\text { ście wspomnianej krytyki tego typu wyjaśniania warto przywołać maksymę Bungego, według której: „odrzucá́ } \\
\text { wyjaśnianie statystyczne byłoby rzeczą równie niemądrą, jak uznawać je za ostateczne” (Bunge, 1968, s. 366). }\end{array}$ \\
\hline \multicolumn{3}{|r|}{ rodzaj relacji eksplanans-eksplanandum } \\
\hline 6 & $\begin{array}{l}\text { Przez prawo wła- } \\
\text { sne (teorię, hipo- } \\
\text { tezę) }\end{array}$ & $\begin{array}{l}\text { Cechuje się tym, że eksplanans wchodzi w relację bezpośrednią z eksplanandum. Nie korzysta się tutaj z analogii, } \\
\text { ale stwierdza wprost, że "dzieje się tak, ponieważ..." (lub „"w danych warunkach zwykle - tzn. statystycznie, } \\
\text { dzieje się tak a tak"). Nazwa tego wyjaśniania nawiązuje do faktu, że dany obiekt wyjaśnia się poprzez prawo } \\
\text { aproksymujące obiektywne prawo danej dziedziny przedmiotowej („prawami własnymi”). Prawo (hipoteza) } \\
\text { użyte do wyjaśniania musi charakteryzować się odpowiednią „zdolnością wyjaśniającą" (por. Nikitin, 1975, } \\
\text { s. 49-51). }\end{array}$ \\
\hline 7 & Modelowe & $\begin{array}{l}\text { Stosowane jest w nauce współczesnej coraz częściej, ponieważ obiekty rzeczywiste bywają niedostępne (naj- } \\
\text { częściej ze względu na ich złożoność oraz trudności w poznaniu bezpośrednim). Model odgrywa wtedy rolę } \\
\text { pośrednika odwzorowującego rzeczywistość, a prawa własne modelu są użyte w eksplanansie jako prawa } \\
\text { wyjaśniające. Aby procedura taka była prawomocna, model musi spełniać określone warunki. Dwa najważ- } \\
\text { niejsze to izomorfizm i homomorfizm. Pierwszy zakłada, że model musi być podobny do oryginału, drugi } \\
\text { zaś, że musi być od niego różny, gdyż inaczej modelowanie nie miałoby sensu (Bunge, 1968, s. } 60 \text { i nast.). Ten } \\
\text { rodzaj wyjaśniania bywa czasem krytykowany ze względu na fakt, że często występuje w nim analogia, pod- } \\
\text { czas gdy model klasyczny opiera się na dedukcji. }\end{array}$ \\
\hline
\end{tabular}

Źródło: opracowanie autora na podstawie prac: Nikitin (1975), Waszczyk, Szczerbicki (2003) i Apanowicz (2000).

z kwestią odkrycia prawdy uniwersalnej w szczególny sposób uwidaczniają się na gruncie nauk społecznych, w których obrębie jest stosunkowo niewiele uniwersalnych generalizacji. Dlatego też w naukach tych szeroko stosowane jest wyjaśnianie probabilistyczne ${ }^{9}$, które odwołuje się do uogólnień wyrażających arytmetyczny stosunek jednego zjawiska do drugiego ( $n$ procent $X=Y$ ), albo jest uogólnieniem wyrażającym określone tendencje/ skłonności ( $X$ ma skłonność do wywoływania Y). Najważniejszym ograniczeniem generalizacji probabilistycznych (indukcyjnych) jest to, że w porównaniu do praw ogólnych, wnioski dotyczące konkretnych przypadków nie mogą zostać wyprowadzone z całkowitą pewnością ${ }^{10}$. Według niektórych badaczy wyjaśnianie pro- 
babilistyczne $\mathrm{w}$ istocie jest jednak tylko jednym $\mathrm{z}$ rozszerzeń klasycznego modelu wyjaśniania, które wynika $\mathrm{z}$ tego, że w naukach empirycznych - oprócz praw jednoznacznych - występują także prawa statystyczne, według których wystąpienie zdarzeń określonego rodzaju jest prawdopodobne, jeśli wystąpią zdarzenia innego rodzaju.

Pomimo przedstawionej mnogości i różnorodności, w praktyce najczęściej stosowane są jednak trzy bazowe rodzaje wyjaśniania: teleologiczne (celowościowe), genetyczne i funkcjonalne, których podstawowe charakterystyki zaprezentowano $\mathrm{w}$ tab. 2 .

W badaniach nad turystyką - pomimo że prowadzą je reprezentanci rozmaitych nauk, w których znaczenie poszczególnych funkcji, jakie są im przypisywane, nie zawsze jest takie samo, a w badaniach wykorzystuje się różne rodzaje aparatów metodologicznych - to właśnie wyjaśnianiu przypisuje się zwykle kluczowe znaczenie ${ }^{11}$. Uznaje się bowiem, że ma ono decydujący wpływ na tworzenie teorii dotyczących zarówno zachowań turystycznych człowieka, jak i skutków turystyki (ekonomicznych, społecznych, kulturowych, środowiskowych itd.). Podobnie - i to w odniesieniu do całej nauki - uważał Popper, który pisał:

Uważam, że celem nauki jest poszukiwanie dobrych wyjaśnień dla wszystkiego, co według nas potrzebuje wyjaśnienia [...], musi to być wyjaśnianie za pomocą sprawdzalnych i falsyfikowanych praw uniwersalnych oraz warunków początkowych. [...] Przypuszczenie, że celem nauki jest poszukiwanie dobrych wyjaśnień prowadzi nas do idei stopniowego poprawienia wyjaśnień poprzez podnoszenie stopnia ich sprawdzalności, to znaczy poprzez przechodzenie do lepiej sprawdzalnych teorii, do teorii o większej treści, wyższym stopniu uniwersalności i wyższym stopniu dokładności (Popper, 1992, s. 252, cyt. za: Strawiński, 2011, s. 323).

wie teorii ma wybór właściwego typu wyjaśniania, które powinno być dostosowane do charakteru badanych zjawisk. Niestety w badaniach turystycznych sytuacja w tym zakresie nie wygląda dobrze, przez co wyjaśnia- nia często mają dosyć ogólny charakter i niezbyt głęboko wnikają $\mathrm{w}$ istotę rzeczy. W takiej sytuacji, gdy zadowalamy się wyjaśnieniami najprostszymi, niektóre ważne kwestie pozostają nieodkryte (niewyjaśnione), lokując się „w ukrytych wymiarach wyjaśniania”.

Jako przykład niech posłuży nam pewien schemat analizy dotyczący wyjaśniania przyczyn braku aktywności turystycznej, przedstawiony przez autora niniejszego artykułu w referacie „Przyszłość w turystyce - turystyka w przyszłości" na IV Forum Turystyki Europejskiej, które odbyło się we Wrocławiu i Polanicy-Zdroju w 2017 r. ${ }^{12}$

Otóż, przyjmijmy hipotetycznie sytuację, w której uzyskujemy informację, że: „Jan nie poleciał na pielgrzymkę do Rzymu". Próbując ją wyjaśnić, dostrzegamy, że na pierwszy plan wysuwa się kwestia braku aktywności (uczestnictwa w tym wyjeździe), a zwłaszcza jej przyczyny / lub przyczyn. Dlatego zapytamy zapewne: „Dlaczego Jan nie poleciał na pielgrzymkę do Rzymu?" (pytanie $\mathrm{nr}$ 1), gdyż tak postępuje się w podstawowym schemacie badań nad aktywnością turystyczną. Dzięki temu pytaniu (z akcentem na "dlaczego") możemy uzyskać odpowiedź dotyczącą przyczyny (czy też przyczyn) zaistniałego faktu, wyjaśniając dzięki temu brak uczestnictwa w pielgrzymce. Ale zastanówmy się nad tym, co się stanie, gdy dokładnie $\mathrm{w}$ tak samo sformułowanym pytaniu inaczej rozłożymy akcenty... i zapytamy:

- Pytanie nr 2: „Dlaczego Jan nie poleciał na pielgrzymkę do Rzymu? " - a np. inni uczniowie w jego klasie albo pracownicy $\mathrm{w}$ firmie polecieli;

- Pytanie nr 3: „Dlaczego Jan nie poleciał na pielgrzymkę do Rzymu? " - tylko np. jadąc samochodem lub pociągiem, stracił na to dwa lub nawet kilka dni;

- Pytanie nr 4: „Dlaczego Jan nie poleciał na pielgrzymkę do Rzymu?" - lecz np. na mecz piłkarski AS Roma - FC Barcelona;

- Pytanie nr 5: „Dlaczego Jan nie poleciał na pielgrzymkę do Rzymu?" - a udał się np. do Fatimy lub Częstochowy?".

Tabela 2. Trzy główne rodzaje wyjaśniania naukowego - ich podstawowe pojęcia i pytania oraz zastosowania w różnych dziedzinach nauk społecznych i humanistycznych

\begin{tabular}{|c|c|c|c|}
\hline $\begin{array}{c}\text { Rodzaj } \\
\text { wyjaśniania }\end{array}$ & $\begin{array}{c}\text { Podstawowe } \\
\text { pojęcia }\end{array}$ & Podstawowe pytanie & Zastosowanie \\
\hline Intencjonalne & $\begin{array}{l}\text { znak } \\
\text { - znaczenie }\end{array}$ & $\begin{array}{l}\text { „"co on chciał przez to osiągnąć/ } \\
\text { powiedzieć?" }\end{array}$ & $\begin{array}{ll}\text { - } & \text { psychologia } \\
\text { - } & \text { hermeneutyka, interpretacje tekstu } \\
\text { - } & \text { niegdyś dominujący rodzaj przyczynowości } \\
& \text { (odczytywanie znaków, przekazów, intencji) }\end{array}$ \\
\hline Funkcjonalne & $\begin{array}{l}\text { struktura } \\
\text { - funkcja }\end{array}$ & $\begin{array}{l}\text { "jaką rolę odgrywa?”, ,"co mu to } \\
\text { załatwia?” }\end{array}$ & $\begin{array}{l}\text { - biologia i nauki przyrodnicze, teoria ewolucji, } \\
\text { - teoria systemówfunkcjonalizm w socjologii } \\
\text { - } \text { ewolucyjne orientacje w psychologii }\end{array}$ \\
\hline Genetyczne & $\begin{array}{l}\text { sytuacja } \\
\text { - geneza }\end{array}$ & $\begin{array}{l}\text { ",jak do tego doszło?", , ,jak to się } \\
\text { stało?" }\end{array}$ & $\begin{array}{l}\text { - } \text { historia } \\
\text { - }\end{array}$ \\
\hline
\end{tabular}

Źródło: opracowanie autora na podstawie: Nikitin (1975), Grobler (2006, s. 251) i Alejziak (2016, s. 7). 
Zwróćmy uwage na to, jak te jedynie inaczej rozłożone akcenty (zdanie pytające było cały czas takie samo: „Dlaczego Jan nie poleciał na pielgrzymkę do Rzymu?”) zmieniają pole analiz oraz eksplanacyjne walory rozumowania, rozszerzając spektrum rozpatrywanych aspektów zjawiska i zwiększając możliwości pełnego wyjaśniania ciągle tego samego faktu, jakim było to, że Jan nie poleciał na pielgrzymkę do Rzymu.

W przypadku każdego z pięciu takich samych zdań (pytań), w których tylko akcent pada na inny wyraz, mamy do czynienia z zupełnie innym obszarem wiedzy o turystyce oraz innymi zagadnieniami wymagającymi zbadania i wyjaśnienia. W pytaniu nr 1 nacisk położony jest na kwestie potrzeb, motywacji i preferencji turystycznych. W pytaniu nr 2 - na problematykę uwarunkowań i czynników decydujących o poziomie i strukturze aktywności turystycznej, a zwłaszcza na kwestie zróżnicowań społecznych w tym zakresie. Pytanie nr 3 dotyczy wielkiego obszaru wiedzy na temat spraw związanych $\mathrm{z}$ rolą transportu $\mathrm{w}$ turystyce, znaczeniem poszczególnych jego form itd. W pytaniu nr 4 zostaje ukazana dodatkowo (oprócz problematyki motywacji) różnorodność oferty, z jakiej mogą korzystać współcześni turyści, oraz form uczestnictwa w turystyce. $Z$ kolei pytanie $n r 5$ otwiera przed nami kolejny wielki obszar wiedzy na temat przestrzeni i geografii turystyki, zróżnicowania lokalizacji atrakcji, kierunków migracji turystycznych itd. Każde $\mathrm{z}$ tych pytań (a właściwie jedno pytanie $\mathrm{z}$ różnie rozłożonymi akcentami) ukazuje zupełnie inny obszar wiedzy o turystyce - z zakresu psychologii, socjologii, ekonomii, marketingu, transportu, geografii itd.- z której w tradycyjnym ujęciu (tzn. bez zróżnicowania akcentowego) nie zdajemy sobie sprawy i w związku z tym nie bralibyśmy ich (tzn. tych dodatkowo odkrytych dzięki innemu akcentowaniu) pod uwagę przy wyjaśnianiu. Co więcej, zwróćmy uwagę na to, że w przypadku większości podanych pytań (numery 2-5) w istocie wcale nie musimy mieć do czynienia z brakiem aktywności turystycznej (brakiem wyjazdu), a jedynie $\mathrm{z}$ różnymi formami uczestnictwa w turystyce.

Przykład ten pokazuje nie tylko problemy i pewne ukryte wymiary wyjaśniania naukowego oraz to, że może mieć ono charakter pragmatyczny, co zależy nie tylko od kontekstu, ale także od osoby wyjaśniającej i osoby oczekującej wyjaśnienia ${ }^{13}$. Podany przykład - który w nawiązaniu do wcześniejszych rozważań dotyczy jeszcze jednego typu wyjaśniania, jakim jest wyjaśnianie erotetyczne (Kuipers, Wiśniewski, 1994) ${ }^{14}$ - ujawnia jednak przede wszystkim, że nie trzeba zamykać się w kręgu badań nad turystyką na nowe ujęcia, że należy starać się odkrywać różne (czasami ukryte) wymiary wyjaśniania naukowego. Jedynie poszukując ciągle nowych inspiracji do wyjaśniania praw i mechanizmów rządzących turystyką, będziemy w stanie formułować nowe pytania i hipotezy badawcze poprzez wychodzenie poza utarte schematy. A wtedy - być może - badane przez nas wszystkich zjawisko ukaże nam swoje inne, ciekawe poznawczo, nieodkryte jeszcze oblicze, a my będziemy mogli powiedzieć, że dobrze przysłużyliśmy się nauce. Dlatego też w dalszej części pracy starano się wykazać związki i zależności wyjaśniania z rozumieniem i przewidywaniem oraz scharakteryzować ich znaczenie dla epistemologicznego wymiaru oraz dalszego rozwoju badań nad turystyką, a w konsekwencji także dla rozkwitu tej ważnej i dynamicznie rozwijającej się dziedziny życia społecznego i gospodarczego.

\section{ROZUMIENIE I PRZEWIDYWANIE JAKO FUNKCJE NAUKI}

Wyjaśnienia naukowe dopiero wtedy stają się rzetelne i wartościowe, kiedy zostaną przetestowane. Testowanie $\mathrm{w}$ dużym stopniu jest związane $\mathrm{z}$ inną funkcją nauki, tj. z przewidywaniem (prewidystyką). W najprostszym ujęciu, jest ono procedurą wyprowadzania wiedzy o przyszłości z wiedzy o przeszłości lub teraźniejszości. O przewidywaniu możemy mówić zarówno w odniesieniu do prognozowania (mówienie o zdarzeniach przyszłych), jak i postgnozowania lub retrognozowania, kiedy odnosimy się do takich faktów, które według nas zaszły w przeszłości, ale nie dokonano ich percepcji (Heller, 1992, s. 32). Przewidywanie i wyjaśnianie, a także rozumienie to takie funkcje nauki, które pozostają względem siebie w relacji komplementarności, choć w aspekcie teoriopoznawczym są „niezastępowalne”.

\subsection{PRZEWIDYWANIE}

Zgodnie z zasadami logiki struktura przewidywania jest z jednej strony tożsama z sytuacją, zachodzącą w strukturze logicznej wyjaśniania, z drugiej zaś - stanowi jej odwrotność15. W obu przypadkach rzecz w tym, że mamy coś wydedukować z pewnego zbioru uznanych praw i zdań o faktach. Różnica dotyczy punktu wyjścia: w wyjaśnianiu jest nim uznane zdanie opisujące fakt, dla którego poszukujemy tłumaczących go racji, natomiast $\mathrm{w}$ przewidywaniu stanowią go pewne uznane prawa oraz zdania o faktach, opisujące spełnione przypadki tych praw - z nich bowiem dedukujemy zdanie opisujace przewidywany fakt, a jego zajście uznajemy za potwierdzenie przewidywania. W przewidywaniu wyprowadza się prognozy oparte na eksplanansie skonstruowanym w procesie wyjaśniania. Nie znaczy to jednak, iż epistemologiczna rola tych dwóch procedur badawczych jest tożsama ${ }^{16}$. Oczekiwanie, że wiedza naukowa powinna prowadzić do dokładnych przewidywań, oparte jest na tezie, że jeśli $X$ wywołuje $Y$ i zaszło $X$, to można przewidywać, że zajdzie $Y$. Oczekiwanie to opiera się na założeniu, że zarówno prawa ogólne, jak i generali- 
zacje probabilistyczne są rozpoznawalne i prawdziwe. Nie zawsze jednak tak jest. Dotyczy to zwłaszcza nauk społecznych, którym często stawiany jest zarzut, że dzięki nim można wprawdzie wyjaśniać określone fakty i zjawiska, lecz w ich przewidywaniu nauki te nierzadko nie są przydatne. Pomocne $w$ tej kwestii okazuje się rozumienie.

\subsection{ROZUMIENIE}

Jak zauważa Ablewicz (2003, s. 92), „,właściwie dopiero ${ }_{\mathrm{w}} \mathrm{XX}$ w. dostrzeżono, że rozumienie stanowi uniwersalną procedurę poznawczą człowieka, wypełniającą i konstytuującą podstawową strukturę jego relacji z samym sobą i z tym wszystkim, co nim nie jest". W porównaniu do pozostałych procedur poznawczych i funkcji nauki (eksplanacji i predykcji) rozumienie dużo trudniej poddaje się definiowaniu i operacjonalizacji (Czarnowska, 1991). Trudność ta wynika z faktu, że sam terminu „rozumienie" używa się $\mathrm{w}$ dwojakim znaczeniu: predyktywnym oraz opartym na empatii, które często określane jest jako rozumienie typu Verstehen ${ }^{17}$.

Rozumienie predyktywne reprezentowane jest głównie przez przedstawicieli tzw. empiryzmu logicznego, którzy wychodzą z założenia, że zarówno w naukach społecznych, jak i przyrodniczych, można uzyskać wiedzę obiektywną, odwołując się do tych samych reguł metodologicznych. Współcześnie takie podejście ma jednak niewielu zwolenników. Dominuje drugie podejście, którego adherenci przyjmują zupełnie odmienne założenie i definiują rozumienie $\mathrm{w}$ kategoriach poszukiwania oraz rozpoznawania znaczeń, kryjących się pod obserwowalnymi przedmiotami (obiektami, faktami, zjawiskami itd.). W podejściu tym zakłada się, że ludzkie działania nie są neutralne aksjologicznie, co powoduje, że wyniki badań (nieneutralne) również są zależne od wartości. Rozumienie - $\mathrm{w}$ tym ujęciu - ma więc na celu przede wszystkim uchwycenie (poprzez wczucie się) tego, co jednostkowe, niepowtarzalne w działaniach człowieka.

Problem rozumienia w szczególności dotyczy nauk społecznych i humanistycznych, w których przedmiotem badania jest człowiek, a badacze są częścią przedmiotu badawczego swojej dyscypliny. Dostrzegał to już M. Weber (reprezentujący nurt tzw. socjologii rozumiejącej), u którego człowiek ukazany jest jako istota dokonująca interpretacji swoich działań oraz poczynań innych ludzi poprzez wskazywanie, że mogą one mieć takie lub inne znaczenia. Uznał on, że skoro ludzie interpretują nawzajem swoje działania, to nie można tego faktu pomijać w konstruowaniu teorii społecznych. Dla rozwoju teorii rozumienia szczególne zasługi ma jednak W. Dilthey, który jako jeden z pierwszych odrzucił pozytywistyczną tezę o metodologicznej jedności nauki. Poszukując obiektywnego statusu poznania humani- stycznego, zerwał on z psychologiczną teorią rozumienia, która wiązała je $\mathrm{z}$ „,wczuciem się" w intencje drugiego człowieka, podczas gdy to właśnie on jest przedmiotem rozumienia. Pokazując mankamenty w dotychczasowej metodologii badań społecznych, Dilthey wskazał jednocześnie na użyteczność, jaką może dla nich mieć podejście hermeneutyczne, według którego rozumienie należy rozpatrywać w łączności ze sprawą ludzkiego bytu oraz ludzkiego poznania. Zasadnicza część dyskusji na temat rozumienia dokonuje się właśnie na gruncie hermeneutyki, która z rozumienia uczyniła podstawowy przedmiot swoich badań (Szulakiewicz, 2004) ${ }^{18}$.

Rozważając istotę i mechanizm rozumienia, wielu autorów posługuje się metaforą koła lub spirali (Ablewicz, 1998; Gadamer, 1993). Przyjmuje się w nich założenie, że jeśli rozumiemy cokolwiek, to poruszamy się naprzód nie w sposób linearny, dodając do siebie kolejno następujące po sobie informacje - tak jak np. są one podawane w czasie. Spotykamy się raczej z ruchem kolistym, w którym droga poznania bierze swój początek $\mathrm{w}$ pewnym punkcie i prowadzi do przedmiotu poznania, biegnąc po okręgu. Gdy poznanie dosięgnie punktu najdalszego, czyli celu - wraca. Jednak powrót nie dokonuje się tą samą drogą, ponieważ wraca ono już odmienione. Musi wrócić do początku, czyli do miejsca, skąd zostało wysłane, ale w efekcie odbytej drogi ono nie jest już to samo. Leży ono nieco wyżej, nad owym punktem wyjścia, i przewyższa poprzednie bogactwem wiedzy. Mamy więc do czynienia ze swoistą spiralą rozumienia.

Taki nieustanny ruch „od... do..." to przede wszystkim ruch od tego, co subiektywne, do tego, co obiektywne. Człowiek zawsze poznaje to, co obiektywne, mając za punkt wyjścia swoją subiektywność. Po zetknięciu z obiektywnym przedmiotem (właściwie nie ma znaczenia, czy jest to natura czy kultura) człowiek wraca „do siebie" i opierając się na własnej subiektywności, buduje indywidualne rozumienie świata i siebie. Od strony formalnej, ruch ten odbywa się według schematu „,od części do całości”, w którym są one ze sobą ściśle powiązane. Zmiana najmniejszej części powoduje jakościową zmianę całości. Każde nowe doświadczenie (przeczytana książka, rozmowa z drugim człowiekiem, kontakt z przyrodą itd.) zmienia człowieka jako całość, zmieniając - w zależności od charakteru doświadczenia $w$ większym lub mniejszym zakresie - jego percepcja świata, postawy wobec rzeczywistości, ludzi itd. Ich sens może zostać prawidłowo odczytany tylko ze względu na życie konkretnego człowieka, postrzegane jako całość.

Termin „rozumienie” często rozpatrywany jest także w szerszym niż przedstawione wyżej znaczeniu, kiedy wykracza on poza proste pojmowanie jego funkcji wobec poznania. Według Landgrebego, rozumienie nie jest wtedy aktem występującym obok poznania, lecz właściwie stanowi fundament poznania. Landgrebe uważa, że zanim uczony rozpocznie swoje badania ma już pewien zasób rozumienia, bowiem: 
Wszystko, co jest nam dane, najpierw i przede wszystkim rozumiemy w jego znaczeniu dla nas. Każde rozumienie „oplecione” jest jakimś znaczeniem. To znaczenie "dla nas" jest tu bardzo istotne, ponieważ dopiero poprzez abstrakcję dochodzimy do czegoś takiego, jak czysty obiekt, który stanowi przedmiot badań (Landgrebe, 1993, s. 200).

Aby zobaczyć ów podmiot badania w takiej właśnie obiektywnej postaci, musimy go sobie intencjonalnie wyodrębnić z doświadczanej przez nas całości. Problemem jednak jest to, że proces tego wyodrębniania już odbywa się według pewnego rozumienia, które buduje określoną perspektywę badawczą. M. Heidegger i H.G. Gadamer nazwali ją przedrozumieniem, a kwestię jego poznawania uznali za jedno $\mathrm{z}$ centralnych pojęć i równocześnie naczelnych zadań hermeneutyki (Czarnowska, 1991).

$\mathrm{W}$ hermeneutyce rozumienie traktowane jest więc nie tylko jako pewien proces poznawczy, lecz znacznie szerzej. Wynika to z założenia, zgodnie z którym człowiek (badacz) doświadcza dwóch podstawowych (w aspekcie epistemologicznym) dla siebie faktów: że jest i że poznaje. Według Ablewicz (2003, s. 94):

w sensie ontologicznym człowiek jest „skazany" na swe rozumiejące istnienie. $W$ tym znaczeniu rozumienie niejako uprzedza naukę, w związku z czym nawet najbardziej aspirujące do obiektywności założenia badań empirycznych, bazujących na teoriach z takich badań wyprowadzonych, wsparte są na przesłankach pozaempirycznych.

Mając to na uwadze, autorka wyróżnia trzy poziomy rozumienia, które pozostają względem siebie $\mathrm{w}$ relacji "nadbudowywania": poziom bycia, poznania oraz badania (Ablewicz, 2003). W takim ujęciu opisana wcześniej struktura koła (spirali), charakterystyczna dla rozumienia, zostaje zachowana (Ablewicz, 1998).

Hermeneutyka poszukuje różnego rozumienia oraz rozmaitych znaczeń, jednak poszukiwania te właściwie nigdy się nie kończą. Przed badaczami otwierają się coraz to nowe konteksty. Rozumienie jest permanentnie otwarte, jego spirala nigdy się nie kończy, a granice między obiektywnością a subiektywnością są nieostre. Aby nie zagubić się w mnogości interpretacji (zwłaszcza jeśli są one równoważne), konieczne jest poszukiwanie tego, co czyni ludzkie porozumienie możliwym. Możliwości takie stwarza fenomenologia, według której każda rzecz, zjawisko czy idea, przedstawione w określonych znaczeniach, skrywają swój sens swoisty (pierwotny), czyli taki, dzięki któremu może ona zostać rozpoznana jako właśnie ona i nic innego. W tym kontekście ważne jest wskazanie istoty wzajemnych relacji pomiędzy fenomenologią a hermeneutyką, a zwłaszcza pamiętanie o tym, że "celem fenomenologii jest wyjaśnianie, a przez to ostateczne uzasadnianie wszelkiego poznania. Aby ten cel osiągnąć, wyłącza ona ze swoich rozważań wszystko, co w jakikolwiek sposób jest «powątpiewalne», co da się usunąć" (Ingarden, 1988, s. 15-16). Współistnienie oraz określone relacje metodologiczne hermeneutyki i fenomenologii okazały się bardzo korzystne dla rozwoju nauk społecznych, $w$ tym także badań nad turystyką (por. Kowalczyk, 2014). W ostatnich latach pojęcie rozumienia stało się kluczowym terminem określającym humanistykę, a hermeneutyka jest czymś w rodzaju epistemologii humanistyki (Szulakiewicz, 2004).

\section{EPISTEMOLOGICZNY WYMIAR ORAZ PROBLEMY PROCESU BADAWCZEGO W TURYSTYCE - ROZWAŻANIA NA GRUNCIE TEORII I MODELI LEWINA I TRIBE'A}

Badania nad turystyką, podobnie jak każda zamierzona i świadomie realizowana czynność ludzka, ukierunkowane są na pewien pożądany efekt, którym $w$ tym przypadku są poznanie i wiedza naukowa na temat tego zjawiska. Dyscypliną, która w szczególny sposób zajmuje się tymi zagadnieniami, jest teoria poznania, znana także pod nazwą epistemologii (Morton, 2002).

Epistemologię interesują stosunki zachodzące między naszymi przekonaniami a światem; warunki, jakie muszą być spełnione, by nasze przekonania zawierały wiedzę, a nie przesądy czy urojenia; wartości, które przypisujemy nośnikom naszej wiedzy, czyli zdaniom - takie wartości zdań, jak: prawdziwość, zasadność, prawdopodobieństwo, moc wyjaśniająca, zdolność prognozowania - oraz racje pozwalające te wartości im przypisywać; funkcje, które pełni wiedza w działaniu. Są dwa pożytki z epistemologii: poznawczy - wiedza ludzka to jeden z najważniejszych i najbardziej zastanawiających problemów poznania, a uprawiana odpowiedzialnie i nowocześnie epistemologia ma o nim sporo do powiedzenia, oraz praktyczny - znajomość ogólnych własności wiedzy, sposobów jej osiągania, reguł odróżniania wiedzy rzetelnej od pozornej ułatwia działanie, szczególnie takie, w którym wiele zależy od zdolności krytycznego poznawania świata, a więc takie, jak np. uprawianie nauki, prowadzenie interesów, kierowanie ludźmi (Morton, 2002, tekst na okładce książki).

Epistemologiczny wymiar procesu badawczego sytuuje się pomiędzy dwoma klasycznymi stanowiskami filozoficznymi: empiryzmem i racjonalizmem. Wydaje się, że wyjaśnienie podstawowych zagadnień epistemologicznych oraz różnic pomiędzy najważniejszymi paradygmatami współczesnej nauki jest niezbędne do dalszych rozważań na temat metodologii badań turystycznych. W przypadku każdego ze wspomnianych stanowisk filozoficzno-metodologicznych (tzn. empiryzmu oraz racjonalizmu) zupełnie odmiennie podchodzi się nie tylko do metodologii badań, ale nawet do tak fundamentalnego pojęcia jak „prawda”. 
Zapewne tym kierował się Tribe, który w paru swoich pracach (pisanych samodzielnie lub w zespołach autorskich) opublikowanych w ciaggu ostatnich kilkunastu lat podejmował tę problematykę $\mathrm{w}$ odniesieniu do wiedzy o turystyce. Początkiem tego swoistego cyklu artykułów wydaje się opracowanie zatytułowane The indiscipline of tourism (1997), w którym - oprócz podstawowej tezy o "niedyscyplinarności” turystyki oraz wykluczeniu możliwości wyodrębnienia jej jako samodzielnej dziedziny nauki - zbudował zarys pewnego teoretycznego modelu, do którego odwoływał się w kolejnych swoich pracach. Dotyczy to także dwóch publikacji, które stanowią swoistą oś rozważań zawartych w niniejszym artykule, gdzie postanowiono nie tylko przedstawić poglądy Tribe'a na temat epistemologicznego wymiaru badań nad turystyką. Szczególną uwagę zwrócono także na ich ewolucję, która w dużym stopniu odzwierciedla zmiany we współczesnej nauce, zarówno w odniesieniu do metodologii badań, jak i do transferowania wiedzy.

Za punkt wyjścia do analiz przyjęto artykuł The truth about tourism (Tribe, 2006), który - w nawiązaniu do tytułu: Prawda o turystyce - nie tylko stanowi znakomite studium na temat epistemologicznych zagadnień badań nad turystyką, ale okazał się także bardzo inspirujący dla dalszych rozważań dotyczących systemu wiedzy turystycznej ${ }^{19}$. W pracy tej autor wykorzystał znaną i dosyć często stosowaną $\mathrm{w}$ różnych dziedzinach nauki (por. Stivers, Wheelan, 1986) teorię pola sił (force-field theory), opracowaną przez Lewina ${ }^{20}$, którą zestawił ze swoimi poglądami zaprezentowanymi we wcześniejszych pracach na temat metodologii badań oraz wiedzy o turystyce. Pojęcie pola sił oddziaływających na tworzenie wiedzy (knowledge force-field) jest używane do opisywania czynników pośredniczących $\mathrm{w}$ procesie translacji świata empirycznego na świat teorii/wiedzy (Levin, 1935, za: Tribe, 2006). Chociaż teoria Lewina nie ma bezpośrednich konotacji i związków z turystyką ${ }^{21}$ okazała się przydatna do analiz procesów tworzenia wiedzy o tym zjawisku. Tribe postanowił wykorzystać ją na potrzeby tych, którzy narzekali na wyraźny niedostatek publikacji dotyczących ontologii i epistemologii badań turystycznych. Nie pierwszy zresztą raz ten wybitny współczesny badacz i teoretyk turystyki ${ }^{22}$ wykazuje się przy tym wyjątkową zdolnością do twórczego wykorzystywania ciekawych koncepcji, powstałych na gruncie innych nauk, $\mathrm{w}$ badaniach nad turystyką. Tym razem stawia fundamentalne pytanie: czy możliwe jest "odkrycie i przedstawienie prawdy o turystyce"? (Tribe, 2006, s. 360).

Przenosząc podstawowe założenia tej teorii Lewina ${ }^{23}$ na grunt badań nad turystyką, Tribe opisuje skomplikowany proces pomnażania dorobku teoretycznego $\mathrm{w}$ tej dziedzinie i ilustruje go schematem (rys. 1), na którym przedstawia podstawowe uwarunkowania i mechanizmy badań turystycznych oraz zachodzące między nimi relacje. Kluczową rolę w całej koncepcji odgrywa właściwa identyfikacja czynników ograniczających (hinder- ing forces) oraz korzystnie stymulujących (helping forces) badane fakty, procesy i zjawiska, a także zachodzace między nimi relacje. $W$ wyodrębnionym przez siebie polu sił wiedzy autor umieścił pięć podstawowych sił, zakodowanych w terminach: osoba (person), reguły (rules), pozycja (position), cele końcowe / korzyści (ends) i ideologia (ideology), wokół których uporządkowane zostały dotychczasowe teorie turystyki oraz uwarunkowania i okoliczności, w jakich one powstawały.

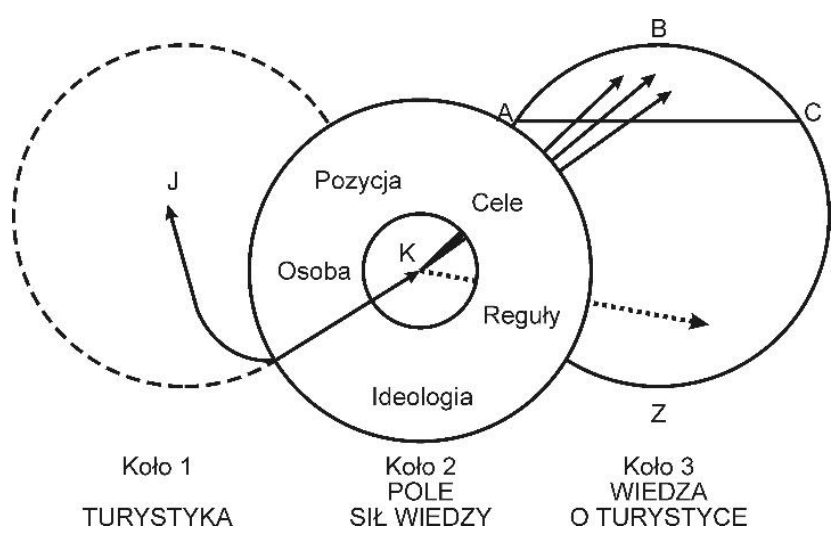

Rysunek 1. Pola sił tworzenia wiedzy w badaniach turystycznych Źródło: Tribe (2006, s. 383)

Przedstawiony na rys. 1 teoretyczny model badań i pozyskiwania wiedzy o turystyce pokazuje, że nigdy nie jesteśmy $\mathrm{w}$ stanie uzyskać pełnego zasoby informacji na jej temat, $\mathrm{m}$.in. dlatego że $\mathrm{w}$ całym procesie badawczym mamy do czynienia z mechanizmem, który Tribe nazywa podwójną selektywnością (double selectivity). Najpierw selekcja taka dokonuje się $\mathrm{w}$ momencie, gdy rzucamy spojrzenie na świat turystyki $(\mathrm{K} \rightarrow \mathrm{J}$, na rys. 1$)$. Już wtedy to, które elementy rzeczywistości turystycznej zostają „oświetlone promieniem tego spojrzenia”, w dużym stopniu zależy od z góry określonych czynników, wypełniających „pola sił kształtujących wiedzę o turystyce" (koło 2), gdyż nie wszystkie problemy mają taką samą szansę przyciągnięcia uwagi badacza. Druga selekcja dokonuje się już w trakcie samych badań, albowiem proces badawczy oraz jego efekty ( $\rightarrow$, czyli koło 2 i 3 ) także podlegają określonym ograniczeniom, jako że są uzależnione od czynników tworzących tzw. pole sił wiedzy (knowledge force-field), czyli czynników pośredniczących w procesie translacji świata empirycznego na świat wiedzy (teorii).

Relacje między realnym światem turystyki (koło $\mathrm{nr} 1$ ) a kanonem wiedzy o nim (koło nr 3) są opisywane i wyjaśniane za pomocą czynników kształtujących wiedzę (koło nr 2), które odgrywają kluczową rolę w całym procesie. Czynniki znajdujące się $\mathrm{w}$ tym polu nie tylko wzajemnie oddziałują na postrzeganie turystyki przez badacza, ale wpływają także na siebie. Na schemacie nie są one przedstawione $\mathrm{w}$ osobnych ramkach, jak to się zwykle czyni, lecz bez nich, dzięki czemu zostaje 
podkreślony fakt, że nie ma pomiędzy nimi możliwych do oznaczenia granic. Każda z pięciu sił stanowi swoisty pryzmat, przez który muszą przejść informacje zdobyte w toku badań, aby znaleźć się w sferze wiedzy o turystyce. Swoje rozważania Tribe oparł na analizie najważniejszych prac z zakresu turystyki oraz ogólnej metodologii nauk, opublikowanych w ciągu ostatnich kilkudziesięciu lat. Starał się wskazać na ich przykładzie różnorodne czynniki - ograniczające oraz korzystnie stymulujące (hindering forces i helping forces, według terminologii Lewina) - które mają wpływ na powstawanie wiedzy o turystyce. Poniżej scharakteryzowano wspomniane pięć grup czynników determinujących proces badawczy oraz mechanizmy tworzenia wiedzy o turystyce ${ }^{24}$ :

- Pole sił wiedzy: czynnik "osoba” (person) - szczególne znaczenie tej grupy czynników wynika z faktu, że to badacz stanowi najważniejsze ogniwo w całym procesie powstawania wiedzy o turystyce. Nieuświadomione, a przez to często $\mathrm{w}$ ogóle niebrane pod uwagę czynniki związane $\mathrm{z}$ „duszą i ciałem” badacza, mają - zdaniem autora koncepcji - duży wpływ na wybierane kierunki i konkretną problematykę badań, stosowane metody i uzyskiwane wyniki ${ }^{25}$. Jednym $\mathrm{z}$ aspektów badań, które dopiero od niedawna są uwzględniane, jest płeć badaczy. Badania przeprowadzone przez Aitchison (1996) wykazały, że liczba mężczyzn wśród autorów publikujących wyniki swoich badań nad turystyką i wypoczynkiem jest czterokrotnie większa niż kobiet, co według tej autorki potwierdza tezę mówiącą o tym, iż tworzenie wiedzy na ten temat ma istotny, choć rzadko uwzględniany wymiar związany z płcią (Aitchison, 1996). Zdaniem Tribe'a $w$ badaniach nad turystyką problemy związane z jednostkowym (a więc subiektywnym) postrzeganiem zjawisk składających się na całościowo pojmowaną rzeczywistość turystyczną mają ogromne znaczenie. Tymczasem bardzo często słowo (zaimek) ,,ja", z uwagi na zawarty w nim ładunek subiektywizmu, jest wręcz zakazane w czasopismach naukowych (np. „Annals of Tourism Research").

- Pole sił wiedzy: czynnik "pozycja” (position) - dotyczy uwarunkowań związanych z kwestią geograficznej lokalizacji ośrodków badawczych (i tego, gdzie mieszkają badacze) zarówno w ujęciu międzynarodowym (zróżnicowany wpływ poszczególnych krajów w tworzenie wiedzy), jak i subnarodowym (dominacja określonych ośrodków naukowych, uczelni, wydziałów itd.). Etnocentryzm, umiejscowienie w jednostkach akademickich oraz przynależność do różnych społeczności akademickich jawią się jako ważne siły mające wpływ na pole czynników kształtujących wiedzę. Analizy publikacji na temat turystyki przeprowadzone przez Tribe'a wskazały, że większość teorii („prawd” - w nawiązaniu do tytułu pracy) składających się na obecną wiedzę o turystyce, dotyczy spraw ważnych raczej dla turysty, a nie dla gospodarza, dla konsumentów, a nie dla pracowników oraz dla przemysłu, a nie dla środowiska, a każda $\mathrm{z}$ tych dychotomii określa interesy grupy dominującej, przeciwstawiając je interesom grupy podrzędnej (Hollinshead, 1999; za: Tribe, 2006).

- Pole sił wiedzy: czynnik "cele końcowe/korzyści” (ends) - należy mieć na uwadze fakt, że to, jakie cele $\mathrm{w}$ danym momencie przyświecają tworzeniu wiedzy, ma duży wpływ na to, czego, jak i gdzie badacze poszukują. W tym kontekście Tribe zwraca uwagę na zjawisko komercjalizacji badań i traktowania wiedzy jako towaru oraz to, jak istotna jest kwestia finansowania badań nad turystyką, jaki udział mają w nim fundusze publiczne oraz jaka jest efektywność ich wykorzystania. Badań takich raczej nie wspierają finansowo wielkie firmy, a nawet całe gałęzie przemysłu, tak jak ma to miejsce np. w przemyśle farmaceutycznym. Środki na badania turystyczne zazwyczaj są bowiem bardzo ograniczone, co czyni z nich, a raczej z podmiotów je przyznających, rodzaj ważnego „selekcjonera" projektów badawczych, który decyduje o kierunkach badań, stosowanych w nich procedurach, metodach itd. Wszystko to ma oczywiście wpływ na wyniki badań, a więc w ostatecznym rozrachunku - na wiedzę o turystyce.

- Pole sił wiedzy: czynnik „ideologia” (ideology) - uwarunkowania tego rodzaju odgrywają dużą - choć nie zawsze dostatecznie uwzględnianą przez badaczy - rolę. Według Tribe'a ich znaczenie może być rozpatrywane $w$ dwóch aspektach. $Z$ jednej strony badania turystyczne $\mathrm{w}$ oczywisty sposób determinowane są przez czynniki ideologiczne (często połączone $\mathrm{z}$ religią), $\mathrm{z}$ drugiej zaś turystyka sama $\mathrm{w}$ sobie jest pewną ideologią, stanowiącą określone ramy dla analizowania historii, przyrody, tradycji itd. Ważniejszy jest ten pierwszy aspekt ideologizacji badań nad turystyką. O znaczeniu owego czynnika kształtowania wiedzy o turystyce świadczy chociażby fakt, że zgromadzona w wyniku dotychczasowych badań oraz dominująca $w$ literaturze światowej wiedza o turystyce reprezentuje głównie poglądy związane z kapitalizmem oraz tzw. kulturą zachodnią. Wiedza ta w żadnym wypadku nie odzwierciedla pełnego zakresu stanowisk ideologicznych, czego przykładem może być to, że w kanonach wiedzy o turystce praktycznie brak teorii opierających się np. na islamskim ${ }^{26}$ czy hinduistycznym punkcie widzenia.

- Pole sił wiedzy: czynnik „reguły” (rules) - dotyczy szeroko pojętej sfery organizacji nauki, w tym struktur i zasad, na jakich prowadzone są badania. Mieszczą się $\mathrm{w}$ tym polu m.in. takie zagadnienia, jak: wielodyscyplinarność, paradygmaty, tradycje, metodologia itd. Wśród nich szczególną rolę odgrywają ograniczenia wynikające $\mathrm{z}$ faktu, że turystyka nie jest samodzielną dyscypliną naukową, co hamuje rozwój badań, a tym samym wpływa na liczebność i ja- 
kość kadry naukowej, mającej z tego powodu pewne trudności na drodze osiągania kolejnych stopni i tytułów naukowych. Tribe pisał też o zjawisku tzw. tyranii dyscyplin (tyranny of the discipline), która występuje w niektórych nowych, interdyscyplinarnych dziedzinach nauki. W turystyce za "dyscyplinarnego tyrana", a jednocześnie swoistego "selektora” decydującego w pewnym stopniu o realizowanych projektach badawczych, uznaje się ekonomię (Franklin, Crang, 2001). Dominacja tej dziedziny sprawia, że „zawłaszcza ona sobie większość najważniejszych społeczno-kulturowych problemów turystyki, traktując ją jako zbiór działalności o charakterze ekonomicznym" (Tribe, 2006, s. 366).

Rozbudowany i kosztowny system tworzenia wiedzy o turystyce (uniwersytety i inne jednostki badawcze, konferencje i sympozja, czasopisma naukowe itd.) istnieje po to, aby odkryć $i$ upowszechnić prawdę o tym zjawisku, która powinna stanowić podstawę wszelkich decyzji związanych z dalszym rozwojem turystyki. Przeprowadzone przez Tribe'a analizy pokazuja, że tworzenie wiedzy w tej dziedzinie to proces skomplikowany, a pole dotyczące kanonu wiedzy o tym zjawisku, zilustrowane na rys. 1 obszarem ABC (górna część koła nr 3), jest znacznie mniejsze od pola zagadnień niezbadanych, nieodkrytych lub niewyjaśnionych, mieszczących się w obszarze AZB. W efekcie koło dotyczace wiedzy o turystyce (nr 3) nie dostarcza wyczerpującej i spójnej wiedzy na temat realnie istniejącej turystyki (koło $\mathrm{nr}$ 1). Pomimo wysiłków podejmowanych przez naukowców zajmujących się turystyką, aby ich badania były rzetelne i wiarygodne, nie tylko nie mówią one całej prawy na jej temat, ale czasami nawet mówią o niej nieprawdę. Przyczyn tego stanu rzeczy oraz odpowiedzi na pytanie: jak poznać prawdę o turystyce?, nie należy jednak szukać tylko wśród mankamentów metodologii badań nad turystyką (a przynajmniej nie tylko tam), ale także w ogólnej metodologii badań. Wynika to $\mathrm{z}$ faktu, że często nie dostrzega się różnego rodzaju ograniczeń wpływających na prowadzone badania, a tym samym na formułowane na ich podstawie teorie. Zdaniem Tribe'a wielu badaczy turystyki postrzega siebie jako "lwy w dżungli", uważając, że w swoich naukowych działaniach nie są praktycznie niczym krępowani, podczas gdy tak naprawdę można ich porównać do „Iwów w cyrku”, które pozostają zamknięte $\mathrm{w}$ klatkach, tworzonych przez ich liczne „strukturalne ograniczenia” (Tribe, 2006, s. 360). Z opiniami tymi zgadza się m.in. Butowski, który uważa, że na wiele pytań dotyczących ontologicznego i epistemologicznego wymiaru turystyki prawdopodobnie jeszcze długo nie będzie jednoznacznych odpowiedzi (por. Butowski, 2011, 2016).

Wskazane w pierwszej części niniejszego artykułu problemy, dotyczące wyjaśniania i rozumienia jako podstawowych funkcji nauki, w pełni ujawniają się w badaniach i teoriach dotyczących różnych aspektów tury- styki. W naukach społecznych, dominujących w przypadku badań i tworzenia wiedzy o tym zjawisku, mamy do czynienia ze współistnieniem różnych nurtów, w których często przyjmuje się zasadniczo odmienne perspektywy badawcze. Tym, co je łączy, jest konstrukcjonistyczny model poznania (Machnikowski, 2011), w którym zakłada się brak możliwości poznania świata w sposób całkowicie niezależny od wpływów kulturowych, przez co nie jest możliwe osiągnięcie obiektywnej prawdy o badanych zjawiskach. Przeciwnicy takiego podejścia zarzucają mu jednak zbyt daleko idące subiektywistyczne interpretacje, zastępujące $\mathrm{w}$ swoich narracjach obiektywną prawdę, która może być nimi substytuowana bez względu na to, czy zawierają one w sobie walory obiektywizmu.

Problematyka jest szczególnie istotna w odniesieniu do tej części nauk społecznych, w których dominują badania jakościowe, gdzie wielu zwolenników ma tzw. teoria ugruntowana, uznawana przez wielu badaczy za najbardziej „obiektywną" metodę prowadzenia badań jakościowych. Ta opracowana w podstawowym zakresie przez A. Straussa oraz B. Glassera koncepcja, która została opisana w książce The Discovery of grounded theory (1967), coraz częściej jest wykorzystywana także w badaniach turystycznych (Matteucci, Gnoth, 2017), ponieważ:

może zaoferować nowy poziom zrozumienia dla badań turystów i ich interakcji z otoczeniem turystycznym. Teoria ugruntowana może generować wyjaśnienia wydarzeń i relacji odzwierciedlających żywe doświadczenia jednostek, grup i procesów, które są centralnym punktem doświadczenia turystycznego (Jennings, Junek, 2007, s. 2002)

Podstawową rolę odgrywa w niej założenie, że rzeczywistość społeczną najlepiej rozumieją zaangażowani w nią aktorzy, którymi powinni być także badacze. Teoria ta odrzuca tradycyjne podejście, $w$ którym badacz analizuje zbiorowość przy użyciu wcześniej opracowanego modelu teoretycznego, przyjmując, że ma to wpływ na swoiste "samopotwierdzanie się" teorii (badacz znajduje to, co chce znaleźć). W związku z tym badania prowadzone są bez prekonceptualizowanych teorii, a w miarę jak w kolejnych czynnościach badawczych (wywiadach, obserwacjach itd.) przybywa informacji i danych, teoria niejako wyłania się z samych badań („gruntuje się"). Istnieją różne odmiany teorii ugruntowanej, które w pewnym stopniu inaczej podchodzą do natury bytu (ontologia), natury wiedzy (epistemologia), sposobów poznawania i uczenia się świata (metodologia) oraz kwestii wartości (aksjologia). Każda z nich ma znaczenie w kształtowaniu się praktyk badawczych oraz interpretowaniu uzyskiwanych dzięki nim wyników. Zwykle wyróżnia się trzy podstawowe odmiany teorii ugruntowanej: obiektywistyczną, postpozytywistyczną i konstruktywistyczną (Matteucci, Gnoth, 2017). Ich podstawowe założenia ontologiczne i epistemologiczne oraz najważniejsze cechy metodologiczne przedstawiono $\mathrm{w}$ tab. 3 . 
Tabela 3. Charakterystyka trzech podstawowych wersji tzw. teorii ugruntowanej (TU)

\begin{tabular}{|c|c|c|c|}
\hline Założenia & Obiektywizm TU & Postpozytywizm TU & Konstruktywizm TU \\
\hline Ontologia & Realizm & Realizm & Realizm \\
\hline Epistemologia & $\begin{array}{c}\text { Empiryzm pozytywistyczny / } \\
\text { obiektywizm }\end{array}$ & Pragmatyzm & Relatywizm \\
\hline $\begin{array}{l}\text { Charakterystyka } \\
\text { metodologiczna }\end{array}$ & $\begin{array}{l}\text { - Badacz jako neutralny obserwator } \\
\text { - Swoboda wypowiedzi } \\
\text { - Wyłonienie się z oczywistych da- } \\
\text { nych } \\
\text { - Obranie za cel odkryć i dążenia do } \\
\text { abstrakcyjnych uogólnien } \\
\text { - Odpowiedzi na pytania „dlaczego?” } \\
\text { - Rygorystyczna procedura kodowa- } \\
\text { nia, napędzająca badania } \\
\text { - Liczba badanych przypadków decy- } \\
\text { dująca o ich obiektywności } \\
\text { - Przegląd literatury po analizie da- } \\
\text { nych }\end{array}$ & $\begin{array}{l}\text { - Refleksyjny badacz } \\
\text { - Wartościowanie wypowiedzi } \\
\text { - Stosowanie wstępnie ustalo- } \\
\text { nych ram do analizy danych } \\
\text { - Dążenie do odkrycia teorii śred- } \\
\text { niego zasięgu } \\
\text { - Definiowanie różnic w wyni- } \\
\text { kach badań } \\
\text { - Przeglądanie literatury przed } \\
\text { analizą danych, w jej trakcie } \\
\text { i po niej }\end{array}$ & $\begin{array}{l}\text { - Refleksyjny badacz } \\
\text { - Wartościowanie wypowiedzi } \\
\text { - Wyłanianie się z interakcji } \\
\text { - Dążenie do budowy teorii śred- } \\
\text { niego zasięgu } \\
\text { - Możliwość generalizacji zależ- } \\
\text { nych (agentycznych), silnie uwa- } \\
\text { runkowanych } \\
\text { - Próbowanie odpowiedzi na } \\
\text { - pytania „co?” i ,jak?” } \\
\text { - Definiowanie różnic w wynikach } \\
\text { badań } \\
\text { - Elastyczne procedury analityczne } \\
\text { - Przeglądanie literatury przed, } \\
\text { w trakcie i po analizie danych } \\
\text { - Stosowanie storytellingu } \\
\end{array}$ \\
\hline
\end{tabular}

Źródło: Charmaz (2011, za: Matteucci, Gnoth, 2017, s. 10).

Badania przeprowadzone przez Matteucciego i Gnotha (2017) wykazały, że wśród badaczy turystyki istnieje stosunkowo słaba znajomość różnic pomiędzy przedstawionymi w tab. 3 odmianami teorii ugruntowanej. Autorzy ci przeanalizowali 48 artykułów opublikowanych $\mathrm{w}$ trzech uznawanych za najlepsze czasopismach naukowych („Annals of Tourism Research" - ATR, „Tourism Management" - TM, i ,Journal of Sustainable Tourism" - JST). Okazało się, że aż w $42 \%$ badanych prac ich autorzy nie podali, którą wersję teorii oraz wynikający z tego "reżim" metodologiczny przyjęli w swoich badaniach. Wersję obiektywistyczną wskazało 10\% autorów, na dwie pozostałe przypadało po $19 \%$ deklaracji (Matteucci, Gnoth, 2017). Podobne wnioski wypływają z badań Stumpfa, Sandstroma i Swangera (2016), którzy zauważyli jednak (na podstawie analizy tym razem 31 prac), że - począwszy od pierwszej publikacji na ten temat, która ukazała się w 1995 r. - zainteresowanie tą metodą $i$ jej zastosowanie $w$ badaniach turystycznych stale rośnie. Zdaniem tych badaczy stwarza to szanse na ciągle oczekiwany znaczący postęp w badaniach nad turystyką oraz lepsze wyjaśnianie i rozumienie zachodzących w niej zjawisk. Oczekiwania te ciągle pozostaja jednak niespełnione, a epistemologiczne, ontologiczne i metodologiczne wymiary badań turystycznych ciągle oceniane są bardzo krytycznie i wielu badaczy uważa, że studia nad turystyką nie mają trwałych i solidnych podstaw teoretycznych oraz nie nadążają za postępem poczynionym $\mathrm{w}$ innych dziedzinach (Benckendorff, Zehrer, 2013).

Zastanawiając się nad przyszłością tych badań oraz nad tym, w jaki sposób można je udoskonalić, po 10 latach od czasu opublikowania szeroko przedstawionego $\mathrm{w}$ tej pracy artykułu The truth about tourism, Tribe posta- nowił jeszcze raz wrócić do problematyki epistemologicznego wymiaru badań i wiedzy o turystyce i w 2016 r. opublikował pracę, w której dokonał istotnych modyfikacji w opracowanym wcześniej modelu. Podstawową zaletą tej modyfikacji jest uwzględnienie wielu elementów (uwarunkowań) nie występujących w modelu pierwotnym, a także podkreślenie wpływu, jaki na procesy powstawania wiedzy naukowej ma transformacja cyfrowa oraz zmiany w systemie komunikacji naukowej. Swoje nowe przemyślenia Tribe zawarł $\mathrm{w}$ napisanym wspólnie z Liburd artykule pt. The tourism knowledge system (Tribe, Liburt, 2016), w którym - odnosząc się do wcześniejszych koncepcji - został przedstawiony nowy model, nazywany systemem wiedzy o turystyce ${ }^{27}$.

W dalszej części pracy zostanie on zaprezentowany w sposób pozwalający łatwo prześledzić zmiany w stosunku do modelu pierwotnego, pokazać jego zalety i wady, a także ocenić jego przydatność do ewaluacji badań nad turystyką oraz wyznaczania ich nowych kierunków. Zgodnie z zapewnieniami autorów (podanymi już w abstrakcie pracy) stosowanie tego nowego modelu - opartego na wcześniejszych badaniach z zakresu ontologii i epistemologii turystyki - pozwala na analizy i wyjaśnienia dotyczące „przestrzeni wiedzy, pól sił wiedzy, sieci wiedzy, czterech kluczowych dziedzin tworzenia wiedzy oraz ich wzajemnych zależności" (Tribe, Liburd, 2016, s. 44). Według autorów koncepcji ma ona służyć lepszemu wyjaśnianiu zjawiska turystyki, w tym zwłaszcza procesów związanych z jego badaniem oraz pozyskiwaniem wiedzy na jego temat. Model (system) przedstawiono na rys. 2 .

Podstawowymi składowymi systemu są elementy starego modelu, gdzie wejście i wyjście stanowią dwa okręgi: nr 1 - świat (turystyki) i nr 4 - wiedza (o turystyce) ${ }^{28}$, 
do których dodano nowe elementy $\mathrm{w}$ postaci: procesów (dwa okręgi: oznaczony jako $\mathrm{nr} 2$ - obejmujący cztery podstawowe dziedziny nauki, w ramach których powstaje wiedza naukowa o turystyce; oraz oznaczony jako nr 3 - dotyczący tzw. wiedzy pozadyscyplinarnej i „pozanaukowej"). Dodatkowymi składowymi są także: granice (owal wewnętrzny - oznaczony jako $\beta$ ), czynniki środowiskowe (owal zewnętrzny - oznaczony jako a) oraz wiele pętli sprzężenia zwrotnego (przerywanych linii: a, b, c, d, e, f) i różne sieci (j, k, m, n), które podkreślają dynamikę systemu, ale też fakt, że wszystkie jego elementy pozostają ze sobą $\mathrm{w}$ określonych relacjach. Powiązane $\mathrm{z}$ literami (a, b, c, d, e, f) dwustronnie skierowane przerywane strzałki podkreślają sprzężenia zwrotne zachodzące pomiędzy wszystkimi czterema podstawowymi elementami systemu (duże okręgi).

Jak widać, pierwotny model Tribe'a poddano głębokiej rekonfiguracji. Został on wzbogacony o wiele nowych elementów, które wymagają omówienia. Przede wszystkim należy zwrócić uwagę na zmiany dotyczące pól sił wiedzy ( $k$ nowledge force-field). Ich liczba wprawdzie nie uległa zmianie, ale modyfikacja jest bardzo istotna. Uzna- jąc, że granice pomiędzy wcześniej wyodrębnionymi polami nie były dostatecznie ostre, a pewne ważne rodzaje sił nie zostały uwzględnione, poprzednie pięć pól zostało połączonych w trzy siły: „osoba”, „pozycja” i ideologia” (uwarunkowania zapisane wcześniej w dwóch pozostałych polach: „regułach” oraz „celach” zostały w nich uwzględnione), a w nowym modelu dodano dwa nowe pola: „rząd” (government) i „globalny kapitał” (global capital). Zmiany te skutkują wzmocnieniem różnorodnych oddziaływań płynących w stronę systemu pozyskiwania wiedzy przez ośrodki władzy i kapitału (przykładem może być z jednej strony program Unii Europejskiej „Horyzont 2020”, z drugiej coraz większy udział, jaki w badaniach naukowych mają wielkie, zwykle ponadnarodowe korporacje).

Szczególnie istotna modyfikacja koncepcji dotyczy tego, że w nowym modelu wcześniejsze koło $\mathrm{nr} 2$, filtrujące wiedzę wynikającą z badań nad turystyką, zostało zastąpione dwoma kołami/okręgami (nr 2 i nr 3), które dotyczą dwóch odrębnych podsystemów pozyskiwania wiedzy. Pierwszy (nr 2) dotyczy wiedzy „produkowanej" w środowisku akademickim w ramach czterech

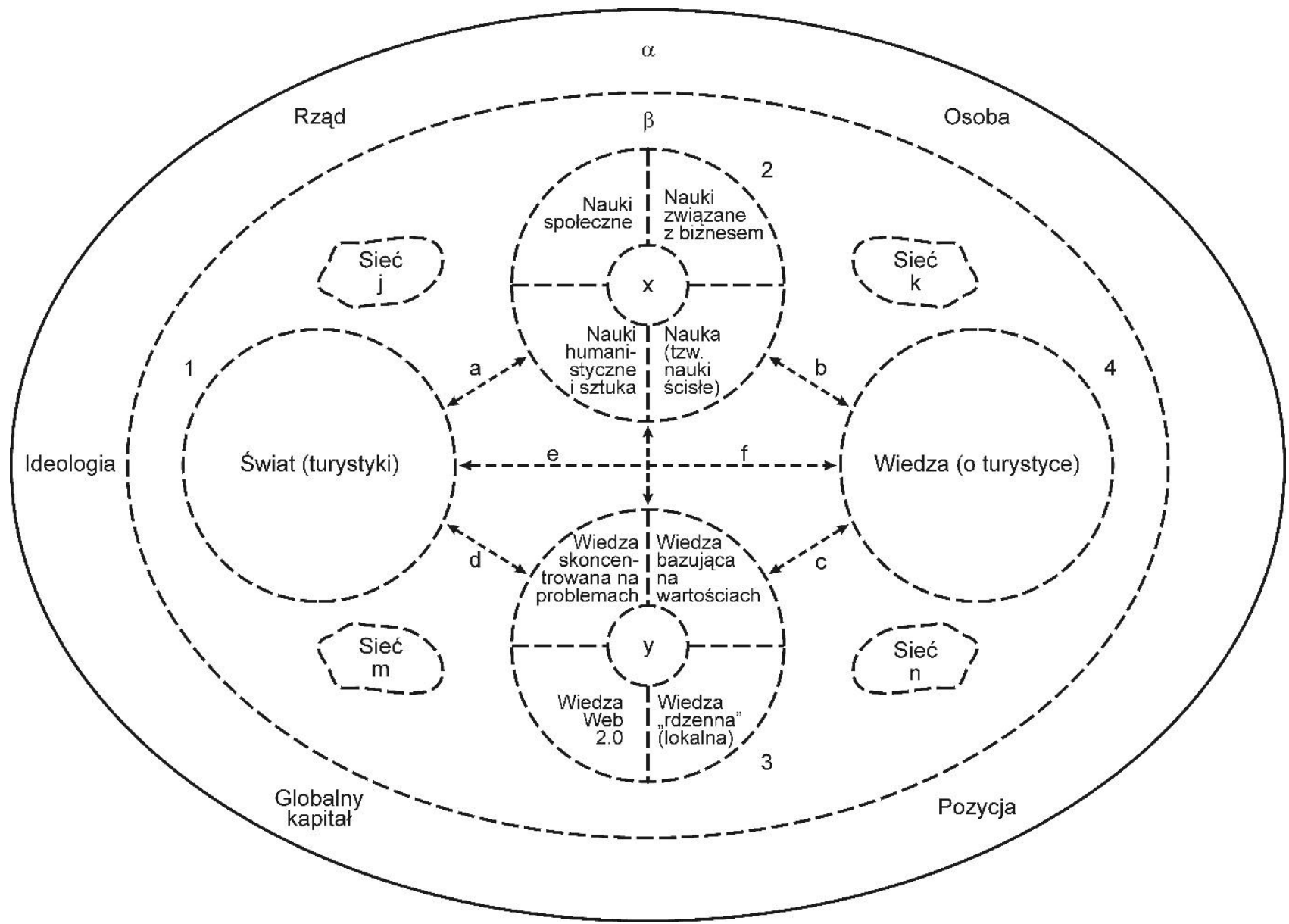

Rysunek 2. System wiedzy turystycznej według Tribe'a i Liburd. Zmodyfikowana koncepcja teorii pól sił wiedzy ( $k$ nowledge force-field) w badaniach turystycznych Źródło: opracowanie własne na podstawie: Tribe, Liburd (2016, s. 46) 
podstawowych dziedzin nauki, podczas gdy drugi (nr 3) dotyczy wiedzy pozyskiwanej poza nim (np. w ramach różnego rodzaju ekspertyz, raportów różnych organizacji itd.). Innymi nowymi elementami są małe wewnętrzne "okręgi" w obu tych polach (zaznaczone przerywaną linią), które oznaczono literami " $\mathrm{x}^{\prime \prime}$ oraz " $\mathrm{y}^{\prime}$. Pierwszy z nich $\left({ }^{\prime} x^{\prime \prime}\right)$ ma symbolizować swoistą płynność badań nad turystyką, która powoduje przenikanie się wiedzy uzyskanej w ramach różnych dziedzin i dyscyplin. Strefa " $x$ " to przestrzeń, $w$ której dochodzi do sprzężeń wiedzy uzyskiwanej w ramach różnych dyscyplin nauki.

Cały okrąg nr 2 został podzielony na cztery obszary: dwa $\mathrm{z}$ nich dotyczą dziedzin mających kluczowe znaczenie dla badań nad turystyką, czyli nauk społecznych oraz nauk o biznesie, a dwa pozostałe dotyczą nauk humanistycznych i sztuki (zwłaszcza filozofii i historii) oraz nauk ścisłych, które - chociaż mają mniejsze znaczenie - mogą istotnie wzbogacić wiedzę o turystyce oraz rozumienie związanych z nią zjawisk. Autorzy koncepcji podkreślają znaczenie faktu, że wobec pewnych ograniczeń nauk społecznych oraz nauk o biznesie w zakresie tego, aby tworzyć kreatywne wizje przyszłości, humanistyka i sztuka oferują niezwykle cenną w takiej sytuacji możliwość pogłębienia zrozumienia przeszłych, obecnych i przyszłych wizji turystyki (Tribe, Liburd, 2016, s. 48). Ich zdaniem również przedstawiciele nauk ścisłych dostarczają wartościowej wiedzy na temat różnorodnych zagadnień związanych z turystyką i ważnych dla turystyki (np. projektowanie samolotów, budownictwo, zastosowanie systemów informatycznych i wykorzystanie Internetu czy medycyna). Podając pewne przykłady prac z tego zakresu ${ }^{29}$, autorzy wyraźnie podkreślają jednak ",słabe zaangażowanie nauk ścisłych w dotychczasowej akademickiej analizie turystyki" (Tribe, Liburd, 2016, s. 49).

Pole wyznaczone przez okrąg nr 3 dotyczy wiedzy pozadyscyplinarnej, pozyskiwanej „poza akademią”. Podzielono je na cztery części: wiedzę skoncentrowaną na problemach (problem-concentred knowledge); wiedzę opartą na wartościach (value-based knowledge); wiedzę rdzenną (indigenous knowledge) oraz wiedzę, 2.0 (Web 2.0 knowledge). Wiedza skoncentrowana na problemach jest szczególnie istotna dla praktyków (bywa nazywana „wiedzą w praktyce") i zwykle ma postać wiedzy milczącej (tacit knowledge). Może mieć nawet słabe oparcie w badaniach, za to jej intencją jest dobre rozumienie oraz praktyczne zastosowanie. Nazywana jest przez autorów „wiedzą ekstradyscyplinarną", a jako jej przykłady mogą posłużyć raporty UNWTO, OECD, UE, prace badawczo-rozwojowe specjalistów branżowych, konsultantów itd. Dostrzegając to, że wiedza skoncentrowana na rozwiązywaniu praktycznych problemów sama może czasami generować problemy, autorzy akcentują znaczenie wiedzy opartej na wartościach, która - niezależnie od zapobiegania nadmiernemu „upraktycznieniu” - ma także określone walory związane z zabezpieczeniem przed zbytnią dominacją i „uteoretyzowaniem” rzeczywistości przez wiedzę płynącą z pola $\mathrm{nr} 2$.

Osobny obszar w polu nr 3 stanowi wiedza Web 2.0. To problematyka szczególnie bliska Liburd, która w tej kwestii wnosi do tworzonego systemu nowe, wartościowe elementy, rozumiejąc, jak wielkie znaczenie ma dzisiaj fakt, że „,w przeciwieństwie do pasywnego przeglądania i pobierania przetworzonych informacji, Web 2.0 odnosi się do zasad i praktyk ułatwiających wymianę informacji i interakcję społeczną poprzez tworzenie, zmienianie i przesyłanie treści internetowych przez użytkowników"(Tribe, Liburd, 2016, s. 51) 30. Wprawdzie w ramach Web 2.0 rozpowszechniana jest przede wszystkim wiedza popularnonaukowa (po części za pośrednictwem mediów społecznościowych, takich jak: Twitter, Facebook) i dla komunikacji stricte naukowej ma ona nie aż tak duże znaczenie, ale jednak dynamiczny rozwój blogosfery naukowej, a także specjalistycznych portali dedykowanych nauce, takich jak: Academia.edu czy ResearchGate, zmieniają sytuację w tym względzie (Alejziak, Liszewski, 2016). Bez wątpienia Web 2.0 ma wielki wpływ na systemy transferowania wiedzy (Cisek, 2008). Jeszcze innym megazjawiskiem w obszarze komunikacji naukowej, o którym warto w tym momencie wspomnieć, jest Open Acces (OA), mający kluczowe znaczenie dla kwestii upowszechniania wyników badań (Maciejewska, Moskwa, Urbańczyk, 2007). Trudno nie zgodzić się z opiniami Tribe'a i Liburd, którzy twierdzą, że w dzisiejszych czasach, „, dążąc do epistemologii pluralistycznej, produkcja wiedzy jest kwestią ciągłej refleksji producentów, nabywców i użytkowników. Web 2.0 rozwija się w oparciu o multi-, inter- i ekstradyscyplinarną wiedzę dostarczaną przez użytkowników tworzących i wspólnie na to pracujących" (Tribe, Liburd, 2016, s. 51).

Czwarty obszar w polu nr 3 dotyczy wiedzy rdzennej - odnoszącej się do określonych kultur, uwarunkowanych położeniem geograficznym, tradycjami, a nawet lokalnymi wierzeniami - ontologicznie i epistemologicznie powiązanej z konkretną społecznością ${ }^{31}$. Wiedza ta często postrzegana przez "zachodnią wiedzę" jako gorsza, przesądna, a nawet zacofana - pomimo swojej kontekstowości - okazuje się przydatna w wyjaśnianiu licznych zjawisk i procesów zachodzących na wielu obszarach recepcji turystycznej (zwłaszcza egzotycznych). Uwzględnienie tych zagadnień wpisuje się $\mathrm{w}$ postulowany przez niektórych badaczy program epistemologicznej dekolonializacji turystyki lokalnej (a new agenda for local tourism epistemological decolonisation) (Chambers, Buzinde, 2015, s. 8) oraz ograniczenie dominacji języka angielskiego w kształtowaniu się wiedzy o turystyce, dzięki czemu zyskałaby ona lepszy epistemologiczny wymiar, w którym brałoby się pod uwage jej postrzeganie i rozumienie także z perspektywy lokalnej (Dann, 2011; Tribe, Dann, Jamal, 2015). 
Ważnym elementem pola nr 3 jest także mały (zaznaczony przerywana linią) okrąg "y", znajdujący się $w$ jego centrum. Wyznacza on pole ścierania się oraz wzajemnego przenikania pozyskiwanej $\mathrm{w}$ tym polu wiedzy, podkreślając przy tym różnorodność form i kanałów, którymi jest ona nie tylko zdobywana, ale także transferowana. Zdaniem autorów koncepcji strefa $y$ jest dobrym miejscem na zadawanie nowych pytań oraz szukanie odpowiedzi, które mogą prowadzić do nowych kierunków badań.

Ostatni nowy element $\mathrm{w}$ prezentowanym modelu stanowią sieci wiedzy, przedstawione na schemacie jako obłoki (oznaczone literkami: j, k, m, n), które krążą wokół poszczególnych elementów systemu. Nadając im kształt chmur, autorzy chcieli podkreślić ich metaforyczny kontrast $\mathrm{z}$ pozostałymi elementami systemu; mieli na uwadze to, że "chmury rosną, łączą się, są płynne, są w ruchu, unoszą się, rozpuszczają, tworzą ponownie" (Tribe, Liburd, 2016, s. 55). Ten element systemu wyraźnie nawiązuje do wcześniejszej pracy Tribes, territories and networks in the tourism academy (Tribe, 2010), w której autor na potrzeby analizy wiedzy turystycznej połączył paradygmat mobilności z teorią sieci aktorów (actor-network theory - ANT). Umieszczając w swoim modelu ten nowy element, autorzy modelu mieli na myśli zarówno sieci całkowicie lub częściowo sformalizowane (TRINET, ATLAS, CAUTHE, IAST), jak i zupełnie nieformalne, opierające się na prywatnych kontaktach badaczy. Ciekawym i podanym w artykule przykładem jest inicjatywa CTS (critical tourism studies), która ukształtowała się w związku z przygotowaniami do konferencji, zorganizowanej w Dubrowniku w 2005 r., oraz w czasie jej trwania, a która pozostaje elastycznym i otwartym na nowych członków forum dyskusji na temat nowych kierunków badań turystycznych.

Na koniec należy podkreślić, że w nowej wersji modelu wcześniejsza "podwójna selektywność” (double selectivity) w produkowaniu (powstawaniu) wiedzy o turystyce - na skutek uwzględnienia dodatkowych elementów i wzbogacenia całej koncepcji o takie aspekty, jak: retoryka badaczy (researcher's rhetoric), punkt widzenia odbiorców (audience gaze) i interpretacja odbiorców (audience interpretation) - zmienia się $\mathrm{w}$ pięciokrotną selektywność (five-fold selectivity) (Tribe, Liburd, 2016). Stało się tak z wielkim pożytkiem dla eksplanacyjnych walorów modelu, gdyż te dodatkowe elementy umożliwiły zauważenie licznych przeoczonych wcześniej uwarunkowań, które mogły wywierać niekorzystny wpływ na procesy "produkowania" oraz „konsumowania” wiedzy o turystyce.

Porównanie starego i nowego modelu ilustrującego system badań turystycznych pozwala stwierdzić, że nowa wersja stanowi całościowy i głęboko przemyślany koncept, który uwzględnia praktycznie wszystkie uwarunkowania tych badań oraz ma znacznie większy potencjał w zakresie naukowego wyjaśniania różnych zjawisk za- chodzących w turystyce oraz "dookoła” niej. Jego podstawową zaletą jest uniwersalny charakter oraz zaakcentowanie elastyczności całego procesu kształtowania się wiedzy o turystyce, z jakim mamy do czynienia obecnie. Nie znaczy to, że model ten jest idealny, zwłaszcza w kontekście uwarunkowań natury ogólnej (dotyczącej generalnie wyjaśniania i rozumienia $w$ naukach społecznych), opisanych w pierwszej części pracy. Wydaje się jednak, że jest to najbardziej wszechstronny i najpełniejszy opis systemu badań turystycznych, jaki został przedstawiony $w$ literaturze, i wart jest rozpowszechnienia zwłaszcza wśród młodszych badaczy turystyki, którzy będą kształtować kierunki badań nad turystyką w najbliższych latach.

\section{PODSUMOWANIE}

Turystyka, jako zjawisko rozwijające się dynamicznie i podlegające ciągłym zmianom, sprawia, że muszą zmieniać się też dotyczące jej badania (Rojek, Urry, 1997). Zasygnalizowane $\mathrm{w}$ tej pracy problemy związane $\mathrm{z}$ rozumieniem i wyjaśnianiem naukowym oraz metodologia badań nad turystyką powodują konsekwencje natury epistemologicznej. Dotyczą one przede wszystkim charakteru wiedzy zdobytej $w$ toku rozumienia i wyjaśniania naukowego, a co za tym idzie - także prawdy o turystyce, która traci walor obiektywności i przynajmniej w pewnej części staje się zrealatywizowana ${ }^{32}$. W takiej sytuacji wzrasta znaczenie epistemologii i hermeneutyki, w których upatruje się najbardziej twórczych, z teoriopoznawczego punktu widzenia, kierunków tych badań (Botterill, 2001). Charakterystyczny dla tych nauk nacisk na podmiotowość - przeciwstawiany instrumentalnej logice pozytywizmu - postrzegany jest jako szczególna szansa dla lepszego zrozumienia fenomenu turystyki oraz znaczenia towarzyszących jej zjawisk. Opiera się on na założeniu, że struktury i procesy społeczne są zbyt złożone, aby je w pełni wyjaśnić za pomocą nawet najbardziej poprawnie stosowanych metod obserwacji. Dlatego też badacz turystyki musi umiejętnie łączyć intuicję z interpretacją, gdyż założenie, zgodnie z którym ktoś może być całkowicie obiektywny i zdolny do zobaczenia świata "takiego, jaki jest naprawdę", należy w świetle dzisiejszej wiedzy ostatecznie odrzucić (Davis, 2001, s. 129). Pomimo że podejście hermeneutyczne też ma wady33, wydaje się, że to właśnie ono oraz inne koncepcje metodologiczne wyrastające z nowych trendów w "filozofii uprawiania nauki" (w tym zwłaszcza związanych z podejściami zintegrowanymi - interdyscyplinarnym i systemowym) będą miały decydujący wpływ na kierunki dalszego rozwoju badań nad turystyką. $W$ badaniach tych, mając na uwadze także opinie o postdyscyplinarności turystyki (Coles, Hall, Duval, 2005), powinno się odejść 
od tradycyjnych ujęć w kierunku bardziej elastycznych form tworzenia wiedzy naukowej. Dotyczy to praktycznie wszystkich elementów składających się na ogólnie pojętą metodologię badań nad turystyką: nowych koncepcji, metod, technik, narzędzi badawczych, a także systemów transferowania wiedzy, które również ulegają zasadniczym modyfikacjom (Alejziak, Liszewski, 2016). Przedstawione $\mathrm{w}$ tej pracy poglądy, teorie i koncepcje wpisują się w te oczekiwania, a dwa szczegółowo przeanalizowane modele mogą stanowić dobry punkt odniesienia przy dalszych poszukiwaniach nowych ujęć i kierunków badań nad turystyką.

\section{PRZYPISY}

${ }^{1}$ Taka opinia ma swoje źródło w dosyć popularnej tezie o symetrii wyjaśniania i przewidywania, według której każdy schemat wyjaśniania może służyć do przewidywania (tzn. jeżeli A wyjaśniamy przez B, to na podstawie B możemy przewidzieć A). Problematyka ta ( $w$ tym także pewne kontrowersje dotyczące tezy o symetrii wyjaśniania i przewidywania) w interesujący sposób została przedstawiona m.in. w pracach: Aspects of scientific explanation (Hempel, 1965) oraz Wyjaśnianie a przewidywanie (Woleński, 1979).

2 Pogląd ten nawiązuje do arystotelesowskiego podziału wiedzy na demonstratywną (odpowiadającą na pytanie ,jjak?") i teoretyczną (odpowiadającą na pytanie „dlaczego?"). W istocie o wyjaśnianiu mówimy również w przypadku takich pytań, jak: „,W jakim celu?", ,kto?", , jak?", ,"co?", "gdzie?”, skąd?", a także „czy zdarzenie zaszło z konieczności?" (Nikitin, 1975, s. 10-13).

${ }^{3}$ Według L. Nowaka pierwsza ze wskazanych perspektyw znajduje wyraz w koncepcji wyjaśniania dedukcyjno-nomologicznego. Jego zdaniem, „jednym z rozszerzeń tego modelu jest wyjaśnianie probabilistyczne, które uwzględnia fakt, że w naukach empirycznych obok praw jednoznacznych, występują także prawa statystyczne, głoszące, że wystąpienie zdarzeń określonego rodzaju jest prawdopodobne, jeśli wystąpią zdarzenia innego rodzaju" (Filozofia a nauka. Zarys encyklopedyczny, 1987, s. 741).

${ }^{4}$ Czasami nazywany jest on modelem podciągania pod prawa (covering-law model).

${ }^{5}$ Zapis oraz charakterystykę schematu zaczerpnięto z polskiego tłumaczenia fundamentalnej pracy Hempela (2001) Filozofia nauk przyrodniczych (przełożonej przez B. Stanosz), dokładnie z rozdziału 5 pt. Prawa i ich rola w wyjaśnianiu naukowym, które dostępne jest na stronach: http://www.dziejemysli.republika.pl/hempel.fnp5.htm oraz http://bacon.umcs.lublin.pl/ lukasik/wpcontent/uploads/2014/02/C.-G.-Hempel-Filozofia-nauk-przyrodniczych-r.-6.pdf.

${ }^{6}$ Uznali jednocześnie, że różne rodzaje wyjaśniania można klasyfikować na podstawie trzech podstawowych kryteriów: charakteru praw stosowanych w eksplanansie, charakteru eksplanandum oraz relacji zachodzących pomiędzy eksplanansem a eksplanandum (Waszczyk, Szczerbicki, 2003).

7 Wyjaśnianie teoriologiczne jest często uważane za wyjaśnianie interteoretyczne, czyli oparte na redukcji. $\mathrm{W}$ istocie tak nie jest, gdyż redukcja - w intencji twórców programu unifikacji nauk (Koło Wiedeńskie) - miała przede wszystkim zapewnić jedność nauk, poprzez sprowadzenie podstawowych zasad metodologicznych dyscyplin (teorii) mniej rozwiniętych teoretycznie do terminów, obiektów i zasad (teorii), występujących w najlepiej rozwiniętych dziedzinach (a zwłaszcza fizyce) (Waszczyk, 1996).
${ }^{8}$ Na przykład, według Waszczyka i Szczerbickiego (2003), $\mathrm{w}$ naukach ekonomicznych dominuje wyjaśnianie statystyczno-faktologiczno-modelowe i koegzystencjalno-faktologiczno-modelowe.

${ }^{9}$ Według niektórych autorów prawdopodobieństwo stało się fundamentalnym pojęciem nauki w XXI w. (por. Nekrases, 1992).

${ }^{10}$ Jeżeli np. wiadomo, że $\mathrm{w}$ danym roku $\mathrm{w}$ wyjazdach połączonych z minimum jednym noclegiem poza miejscem zamieszkania brało udział $60 \%$ Polaków posiadających wykształcenie wyższe, to nie możemy wnioskować z całkowitą pewnością, że prawdopodobieństwo takiego wyjazdu w przypadku konkretnego Polaka, legitymującego się wyższym wykształceniem, wyniesie $\% 110$. Wynika to $\mathrm{z}$ faktu, że na zachowanie konkretnych osób wpływają inne (oprócz uwzględnionego tu poziomu wykształcenia) czynniki. Osoba taka może być np. miłośnikiem gór oraz członkiem stowarzyszenia turystycznego, co zwiększa prawdopodobieństwo uprawiania turystyki (mogą to być też wyjazdy wielokrotne). Z drugiej strony, jeśli będzie to np. osoba niepełnosprawna, to prawdopodobieństwo jej wyjazdu wyraźnie się zmniejszy.

${ }^{11}$ Według Z. Chojnickiego we współczesnej filozofii nauki dominuje pogląd o podstawowym znaczeniu roli wyjaśniania, które wyznacza sens poznawczy i ramy postępowania badawczego, co nie oznacza jednak braku konieczności ciąłego poszukiwania nowych ujęć i koncepcji wyjaśniania, które byłyby dostosowane do charakteru poszczególnych dziedzin nauki. Warto dodać, że ten wybitny reprezentant geografii społeczno-ekonomicznej - dostrzegając trudności związane z zastosowaniem modelu dedukcyjno-nomologicznego (zwłaszcza w naukach społecznych) - propagował relacjonistyczne ujęcie wyjaśniania, które - jego zdaniem - ,jest postępowaniem nie tylko uzasadniającym, lecz także odkrywczym, w toku którego ustala się przesłanki wyjaśniania stanowiące wiedzę o procesach i mechanizmach determinujących występowanie faktów, głównie w odniesieniu do realnych systemów społecznych" (Chojnicki, 2002, s. 11-12).

12 Prezentacja wygłoszona na tej konferencji przez autora artykułu dostępna jest pod adresem: https://wtir.awf.krakow.pl/attachments/article/135/wyjasnianie_naukowe_i_rozumienie_w_badaniach_nad_turystyka.pdf.

${ }^{13}$ Dobrze pokazuje to przykład podany przez Groblera, dotyczący pytania: „„«dlaczego nastąpił ten wypadek drogowy?», w którym policjant zapewne zadowoli się odpowiedzią: «Ponieważ kierowca był niezupełnie trzeźwy», inżynier drogowy będzie oczekiwał odpowiedzi, że np. «Łuk szosy był niewłaściwie wyprofilowany», a konstruktor będzie interesował się ewentualnymi wadami konstrukcyjnymi samochodu" (Grobler, 2006, s. 113).

${ }^{14}$ Erotetyka to teoria pytań i odpowiedzi, która zajmuje się m.in. strukturą wypowiedzi pytajnych, założeniami pytań, rodzajami odpowiedzi oraz tzw. rozumowaniami erotetycznymi. Duży wkład w rozwój tego typu wyjaśniania wniósł zwłaszcza van Fraasen w swojej książce The scientific image (1980).

${ }^{15}$ Ta swoista „odwrotność" struktury logicznej wyjaśniania i prognozowania jest przez niektórych kwestionowana. Ciekawie ujętą krytykę tego stanowiska zawiera m.in. praca Motyckiej (1984).

${ }^{16}$ Podobieństwo schematu logicznego, jakim posługujemy się tak w przypadku eksplanacji, jak i prognozowania nie oznacza bynajmniej, że odgrywają one podobną rolę w budowaniu teorii naukowej. W przypadku nauk społecznych mamy do czynienia z osobliwą cechą przewidywania, która nie ma odpowiednika w naukach przyrodniczych. Są to tzw. samorealizujące się oraz samoobalające się przewidywania (np. podanie do publicznej wiadomości wyników badań, które przewidywały zajście określonych zjawisk społecznych, może wpłynąć na postawy i zachowania ludzi w taki sposób, iż w następstwie tej zmiany owe przewidywania się sprawdzą bądź zostaną obalone (por. Pawłowski, 1986).

17 Verstehen - termin wywodzący się z języka niemieckiego (choć używany także w innych językach) i oznaczający rozumienie 
wewnętrzne, za pomocą empatii, intuicji lub wyobraźni. Stanowi przeciwieństwo wiedzy zewnętrznej, wynikającej z obserwacji. Pomimo pewnych związków, a nawet podobieństw, empatia (Einfühlung) i zrozumienie są jednak dwiema zupełnie różnymi postawami. Czym innym jest $n p$. rozumieć dzieło sztuki z historycznego punktu widzenia (np. określić miejsce jego powstania, znaczenie i rolę, jaką odegrało w historii), a czym innym odczuć jego piękno, jako dzieła sztuki.

18 Trzeba jednak pamiętać o tym, że hermeneutyka jest nie tylko nauką, ale - w pewnym sensie - także praktyczną sztuką rozumienia, dającą wskazówki i reguły postępowania w interpretowaniu.

${ }^{19}$ Warto dodać, że koncepcję tę można wykorzystać także do analiz metodologii badań oraz mechanizmów kształtowania się wiedzy w ramach innych dziedzin i dyscyplin nauki. Jako przykład może posłużyć praca Alejziaka (2018) pt. Metodologia nauk prawnych a metodologia badań nad turystyka - w poszukiwaniu podobieństw oraz różnic w paradygmatach i podejściach badawczych, z której zresztą pochodzą niektóre fragmenty wykorzystane $\mathrm{w}$ tym artykule.

${ }^{20}$ Kurt Zadek Lewin (9 IX 1890 r. - 12 II 1947 r.) - urodzony i mieszkający przez pewien czas w Wielkopolsce wybitny psycholog oraz teoretyk organizacji. Był profesorem Uniwersytetu Humboldta w Berlinie, Iowa State University oraz Massachusetts Institute of Technology w Cambridge (był założycielem i dyrektorem Research Center for Group Dynamics w MIT). Jest twórcą kierunku zwanego psychologią topologiczną lub psychologią pola oraz autorem teorii pola sił, na gruncie której zrodziły się inspiracje Tribe'a przedstawione $\mathrm{w}$ tej pracy.

${ }^{21}$ Wykorzystywana jest ona głównie w zarządzaniu i coachingu, jako narzędzie służące do oceny wpływu otoczenia na zmiany, jakie planuje wprowadzić dana jednostka lub organizacja, aby lepiej dopasować się do zmieniających się uwarunkowań ich działalności.

22 Tribe przez wiele lat był m.in. redaktorem naczelnym czasopisma "Annals of Tourism Research", uznawanego za jeden z najlepszych periodyków naukowych z zakresu turystyki na świecie.

${ }^{23}$ Sam Lewin twierdził, że „teorii pola nie można nazwać teorią w zwykłym znaczeniu, ponieważ trudno uznać ją zarówno za poprawną, jak i niepoprawną, a najlepiej scharakteryzować ją jako metodę: mianowicie metodę analizy związków przyczynowych i budowania konstrukcji naukowych" (Lewin, 1943, s. 292).

${ }^{24}$ Opis tych czynników podano za wspomnianą już wcześniej pracą Alejziaka (2018).

25 Tribe podaje konkretne przykłady rzadko uwzględnianych czynników determinujących badania naukowe, takie jak: aspekty etniczne i kulturowe, polityczne, biologiczne, a nawet psychologiczne i związane z osobistym doświadczeniem - np. zauroczenie pewną kobietą, które miało duży wpływ na wybór tematu i zakres badań do pracy doktorskiej, podjętych przez jednego z najlepszych obecnie naukowców zajmujących się turystyką (Tribe, 2006).

${ }^{26}$ Na przykład jeden z kanonów wiedzy o turystyce, który zakłada, że płeć zasadniczo nie różnicuje poziomu aktywności turystycznej, w przypadku społeczeństw, w których dominuje islam, całkowicie nie odzwierciedla rzeczywistości, tylko z tego powodu, że zgodnie $\mathrm{z}$ zasadami tej religii kobieta powinna podróżować wyłącznie w towarzystwie męża, ojca lub brata, podczas gdy mężczyzn takie ograniczenia nie obowiązują.

$27 \mathrm{~W}$ pracy tej autorzy odwołują się do koncepcji dotyczących systemu turystyki oraz systemu wiedzy o turystyce, prezentowanych m.in. w pracach: Leiper (1979), Jafari, Brent, Ritchie (1981).

${ }^{28}$ Warto podkreślić, że okregi te reprezentują świat turystyki i świat wiedzy o turystyce nie jako elementy niezależne, ale część szeroko pojętych osobnych kategorii - świata oraz wiedzy w ogóle.
${ }^{29} \mathrm{Na}$ przykład artykuł dotyczący zastosowania inteligentnych systemów w turystyce, który analizuje to zagadnienie z perspektywy nauk społecznych (Gretzel, 2011), kilka prac z zakresu medycyny podróży, czy też artykuł dotyczący roli turystyki w globalnie postrzeganej wymianie biologicznej, jako efektu przemieszczania się gatunków w ramach turystyki międzynarodowej (Hall, 2015).

30 Jako przykład zastosowania Web $2.0 \mathrm{w}$ badaniach turystycznych autorzy podają program „Ecocean”, który ma na celu nieinwazyjne badanie i ochronę rekinów wielorybich. W ramach tego programu zdjęcia i nagrania wizualne zrobione przez turystów wysyłane są przez nich na specjalną stronę internetową, po czym są one analizowane przez zespół badaczy afiliowany przez NASA i współpracujący z nią ( $w$ badaniach wykorzystuje się techniki i algorytmy stosowane $\mathrm{w}$ mapowaniu gwiazd przy użyciu teleskopu Hubble'a) (Tribe, Liburd, 2016).

31 Bardzo ważnym aspektem tego zagadnienia jest kwestia epistemologicznej autentyczności przy wyjaśnianiu różnych zjawisk turystycznych i związanych z turystyką oraz moralnej odpowiedzialności badacza za przebieg i wyniki prowadzonych badań (w tym tego, w jakim stopniu uda mu się uwzględnić wiedzę rdzenną). Ciekawe rozważania na ten temat przedstawiono w pracy: Autentyczność epistemologiczna jako nakaz moralny wyjaśniania rzeczywistości turystycznych (Kaczmarek, 2018).

32 Przedstawiciele epistemologiczno-hermeneutycznego kierunku badań nad turystyką sugerują, że nawet tak podstawowa kategoria jak przestrzeń może być różnie interpretowana, w zależności od podmiotu w niej występującego. Z uwagi na to, że również (a może szczególnie) w turystyce istnieje możliwość przypisania wielu znaczeń różnym kategoriom (np. przestrzeni, atrakcjom turystycznym, zjawiskom ekonomicznym i społecznym), często powstaje konflikt - które ze znaczeń powinno być wiodące.

33 Przede wszystkim są trudne w realizacji. Trudność sprawia już właściwe rozłożenie akcentów na różnorodnej problematyce i takie prowadzenie badań, aby współpraca interdyscyplinarna - przy uwzględnieniu indywidualności każdej dyscypliny - wzmacniała, a nie osłabiała integrację pola studiów nad turystyką (Maik, 2002)

\section{BIBLIOGRAFIA}

Ablewicz, K. (1998). Hermeneutyka i fenomenologia w badaniach pedagogicznych. W: S. Palka (red.), Orientacje w metodologii badań pedagogicznych (s. 25-41). Kraków: Wydawnictwo Uniwersytetu Jagiellońskiego.

Ablewicz, K. (2003). Teoretyczne i metodologiczne podstawy pedagogiki antropologicznej. Kraków: Wydawnictwo Uniwersytetu Jagiellońskiego.

Aitchison, C. (1996). Patriarchal paradigms and the politics of pedagogy: A framework for a feminist analysis of leisure and tourism studies. World Leisure and Recreation, 38 (4), 38-40.

Alejziak, W. (2005). Present status and perspectives of tourism research development. W: W. Alejziak, R. Winiarski (red.), Tourism in scientific research (s. 257-279). Kraków-Rzeszów: AWF Kraków, WSIZ Rzeszów.

Alejziak, W. (2008a). Metodologia badań w turystyce. W: R. Winiarski (red.), Turystyka w naukach humanistycznych (s. 140-164) Warszawa: Wydawnictwo Naukowe PWN.

Alejziak, W. (2008b). Podstawowe paradygmaty i podejścia badawcze w studiach nad turystyką. W: G. Gołembski (red.), Nowe trendy rozwoju turystyki (s. 13-25). Sulechów: Wydawnictwo PWSZ. 
Alejziak, W. (2013). Typologizacja i modelowanie jako instrumenty naukowego wyjaśniania zjawisk i procesów turystycznych. W: L. Butowski (red.), Badania naukowe w turystyce - stan i perspektywy (s. 9-38). Warszawa: Instytut Turystyki, Szkoła Główna Turystyki i Rekreacji.

Alejziak, W. (2016). Atrybucje i wyjaśnianie przyczynowe w badaniach nad turystyką (na przykładzie analizy inhibitorów aktywności turystycznej Europejczyków w latach 1997-2014). W: Człowiek w turystyce. Role, potrzeby, zachowania (s. 67-90). Warsztaty z geografii turyzmu. Tom 7 . Łódź: Wydawnictwo Uniwersytetu Łódzkiego.

Alejziak, W. (2018). Metodologia nauk prawnych a metodologia badań nad turystyką - $\mathrm{w}$ poszukiwaniu podobieństw oraz różnic $\mathrm{w}$ paradygmatach i podejściach badawczych. W: P. Cybula (red.), Prawne aspekty podróży i turystyki - historia i wspótczesność (s. 51-95). Kraków: Wydawnictwo Uniwersytetu Jagiellońskiego.

Alejziak, W., Liszewski, S. (2016). Rola czasopism naukowych w transferze wiedzy w turystyce. Folia Turistica, 41, 81-135. DOI: https:/ / doi.org/10.5604/01.3001.0010.4005

Apanowicz, J. (2000). Metodologiczne elementy procesu poznania naukowego w teorii organizacji i zarzadzania. Gdynia: WSAiB.

Ballantyne, R., Packer, J., Axelsen, M. (2009). Trends in tourism research. Annals of Tourism Research, 36 (1), 149-152. DOI: https://doi.org/10.1016/j.annals.2008.07.001

Benckendorff, P., Zehrer, A. (2013). A network analysis of tourism research. Annals of Tourism Research, 43, 121-149. DOI: https://doi.org/10.1016/j.annals.2013.04.005

Bogucka, I. (1991). Wyjaśnianie a wyjaśnianie funkcjonalne. Folia Philosophica, 8, 95-114.

Botterill, D. (2001). The epistemology of a set of tourism studies. Leisure Studies, 20 (3), 199-214. DOI: https://doi.org/10.1080/ 02614360127084

Brzeziński, J. (2005). Metodologia badań psychologicznych. Warszawa: Wydawnictwo Naukowe PWN.

Bunge, M. (1968). O przyczynowości. Miejsce zasady przyczynowej we wspótczesnej nauce. Przekład: S. Amsterdamski. Warszawa: PWN.

Butler, R.W. (2015). The evolution of tourism and tourism research. Tourism Recreation Research, 40 (1), 16-27. DOI: https:// doi.org/10.1080/02508281.2015.1007632

Butowski, L. (2011). Turystyka jako dyscyplina nauki (artykuł dyskusyjny). Turyzm/ Tourism, 21 (1-2), 17-24.

Butowski, L. (2016). Tourism as a discipline in light of the nonclassical sociology of science. Journal of Tourism and Cultural Change, 16 (4), 436-454.

Butowski, L. (red.) (2014a). Searching for the scientific identity of tourism research. Warszawa: Warsaw School of Tourism and Hospitality Management.

Chambers, D., Buzinde, C. (2015). Tourism and decolonisation: Locating research and self. Annals of Tourism Research, 51, 1-16. DOI: https://doi.org/10.1016/j.annals.2014.12.002

Charmaz, K. (2011). Grounded theory methods in social justice research. W: N.K. Denzin, Y.S. Lincoln (red.), Handbook of qualitative research (s. 359-380). Los Angeles: Sage.

Chojnicki, Z. (2002). Wyjaśnianie w geografii społeczno-ekonomicznej w ujęciu relacjonistycznym. W: H. Rogacki (red.), Możliwości i ograniczenia zastosowań metod badawczych w geografii spoteczno-ekonomicznej i gospodarce przestrzennej (s. 11-23). Poznań: Bogucki Wydawnictwo Naukowe.

Cisek, S. (2008). Nauka 2.0: nowe narzędzia komunikacji naukowej. Pobrane z: http://eprints.rclis.org/11212/.

Coles, T., Hall, M., Duval, D. (2005). Mobilizing tourism: A postdisciplinary critique. Tourism Recreation Research, 30 (2), 31-42. DOI: https://doi.org/10.1080/02508281.2005.11081471
Czarnowska, M. (1991). Myśl i pojęcie - ku rozumieniu tekstu filozoficznego. Białystok: Zakład Teorii Poznania, Filia Uniwersytetu Warszawskiego.

Dann, G. (2011). Anglophone hegemony in tourism studies today. Enlightening Tourism. A Pathmaking Journal, 1 (1), 1-30.

Dann, G., Nash, D., Pearce, P. (1988). Methodology in tourism research. Annals of Tourism Research, 15 (1), 1-28. DOI: https:// doi.org/10.1016/0160-7383(88)90068-0

Davis, J.B. (2001). Commentary: Tourism research and social theory - expending the focus. Tourism Geographies, 3 (2), 125-134. DOI: https://doi.org/10.1080/14616680010030248

Filozofia a nauka. Zarys encyklopedyczny (1987). Wrocław-WarszawaKraków-Gdańsk-Łódź: Polska Akademia Nauk, Ossolineum.

Fraasen, B. van (1980). The scientific image. Oxford: Oxford University Press.

Frankfort-Nachmias, Ch., Nachmias, D. (2001). Metody badawcze w naukach społecznych. Przekład: E. Hornowska. Warszawa: Wydawnictwo Zysk i S-ka.

Franklin, A., Crang, M. (2001). The trouble with tourism and travel theory? Tourist Studies, 1 (1), 5-22. DOI: https://doi.org/ $10.1177 / 146879760100100101$

Gadamer, H.G. (1993). Koło jako struktura rozumienia. W: Wokót rozumienia. Studia i szkice z hermeneutyki. Wybór G. Sowiński. Kraków: Wydawnictwo Naukowe Papieskiej Akademii Teologicznej.

Gretzel, U. (2011). Intelligent systems in tourism. A social science perspective. Annals of Tourism Research, 38 (3), 757-779. DOI: https://doi.org/10.1016/j.annals.2011.04.014

Grobler, A. (2006). Metodologia nauk. Kraków: Wydawnictwo AUREUS i Wydawnictwo Znak.

Hall, C.M. (2015). Tourism and biological exchange and invasions: A missing dimension in sustainable tourism? Tourism Recreation Research, 40 (1), 81-94. DOI: https:/ /doi.org/10.1080/ 02508281.2015 .1005943

Hall, C.M., Williams, A.M., Lew, A.A. (2004). Tourism: Conceptualizations, institutions, and issues. W: A.A. Lew, C.M. Hall, A.M. Williams (red.), A companion to tourism (s. 3-21). Oxford: Blackwell Publishing.

Heller, M. (1992). Filozofia nauki. Wprowadzenie. Kraków: WAM.

Hempel, C.G. (1965). Aspects of scientific explanation. W: C.G. Hempel, Aspects of scientific explanation and other essays in the philosophy of science (s. 367-403). New York: Free Press.

Hempel, C.G. (2001). Filozofia nauk przyrodniczych. Przekład B. Stanosz. Warszawa: Fundacja Aletheia.

Hempel, C.G., Oppenheim, P. (1948). Studies in the logic of explanation. Philosophy of Science, 15, 135-175. DOI: https://doi.org/ $10.1086 / 286983$

Ingarden, R. (1988). O badaniach Edyty Stein. W: E. Stein, O zagadnieniu wczucia (s. 155-180). Kraków: Wydawnictwo Znak.

Jafari, J. (2001). Scientification of tourism. W: V.Smith, M. Brent (red.), Hosts and guests revisited: tourism issues of the 21st century (s. 28-41). New York: Cognizant Communication Corporation.

Jafari, J., Brent Ritchie, J. (1981). Toward a framework for tourism education: Problems and prospects. Annals of Tourism Research, 991, 13-34.

Jennings, G., Junek, O. (2007). Grounded theory: Innovative methodology or a critical turning from hegemonic methodological praxis in tourism studies. W: I. Ateljevic, A. Pritchard N. Morgan (red.), The critical turn in tourism studies, innovative research methodologies (s. 197-210). Oxford: Elsevier.

Kaczmarek, J. (2018). Autentyczność epistemologiczna jako nakaz moralny wyjaśniania rzeczywistości turystycznych. Folia Turistica, 49, 119-220.

Kowalczyk, A. (2014). Fenomenologia przestrzeni turystycznej. Turyzm, 24 (1), 9-15. 
Kuipers, T.A.F. Wiśniewski, A. (1994). An erotetic approach to explanation by specification. Erkenntnis, 40, 377-402. DOI: https://doi.org/10.1007/BF01128905

Landgrebe, L. (1993). Rozumienie w naukach o duchu. W: Wokót rozumienia. Studia i szkice z hermeneutyki (s. 195-207). Wybór G. Sowiński. Kraków: Wydawnictwo Naukowe PAT.

Leiper, N. (1979). The framework of tourism: Towards a definition of tourism, tourist, and the tourist industry. Annals of Tourism Research, 6 (4), 390-407. DOI: https:/ / doi.org/10.1016/ 01607383(79)90003-3

Lewin, K. (1943). Defining the "field at a given time". Psychological Review, 50, 292-310. DOI: https://doi.org/10.1037/h0062738

Liburd, J.J. (2012). Tourism research 2.0. Annals of Tourism Research, 39 (2), 883-907. DOI: https://doi.org/10.1016/j.annals. 2011.10.006

Lubański, M. (1972). Objasnenie - funkcija nauki, E.P. Nikitin, Moskwa 1970: [recenzja]. Studia Philosophiae Christianae, 8 (1), 237-243.

Machnikowski, R.M. (2011). Spór o relatywizm konstruktywistycznej socjologii wiedzy naukowej. W: P. Bytniewski, M. Chałubiński (red.), Teoretyczne podstawy socjologii wiedzy (s. 61-77). Lublin: Wydawnictwo Uniwersytetu Marii Curie-Skłodowskiej.

Maciejewska, Ł., Moskwa, K., Urbańczyk, B. (2007). Czasopisma naukowe Open Access - model otwartego dostępu do wiedzy. W: IV Ogólnopolska Konferencja EBIB Internet w bibliotekach Open Access. Toruń, 7-8 grudnia 2007 roku - (EBIB Materiaty konferen-cyjne nr 18). Warszawa: Stowarzyszenie Bibliotekarzy Polskich, Redakcja „Elektronicznej Biblioteki”.

Maik, W. (2002). Strategia współpracy nauki i praktyki w zakresie planowania rozwoju turystyki. W: Partnerstwo nauki i praktyki $w$ turystyce. Fakty, intencje, potrzeby rozwoju (s. 41-48). Bydgoszcz: Wyższa Pomorska Szkoła Turystyki i Hotelarstwa.

Matteucci, X., Gnoth, J. (2017). Elaborating on grounded theory in tourism research. Annals of Tourism Research, 65, 49-59. DOI: https://doi.org/10.1016/j.annals.2017.05.003

Morton A. (2002). Przewodnik po teorii poznania. Przekład: T. Baszniak. Warszawa: Wydawnictwo Spacja.

Motycka, A. (1984). Relatywistyczna wizja nauki. Wprowadzenie: filozoficzny spór o naukę. Wrocław: Ossolineum.

Nagel, E. (1985). Struktura nauki. Zagadnienia logiki wyjaśnień naukowych. Warszawa: PWN.

Nekrases, E. (1992). Wiedza prawdopodobna. Warszawa: PWN

Nikitin, E. (1975). Wyjaśnianie jako funkcja nauki. Warszawa: PWN.

Oviedo-García, M.A. (2016). Tourism research quality: Reviewing and assessing interdisciplinarity. Tourism Management, 52, 586-592. DOI: https://doi.org/10.1016/j.tourman.2015.08.011

Pawłowski, T. (1986). Tworzenie pojęć w naukach humanistycznych. Warszawa: PWN

Pearce, D.G., Butler, R.W. (1993). Tourism research: Critiques and challenges. London: Routledge.

Ritchie, B., Burns, P., Palmer, C., (2005). Tourism research methods: Integrating theory with practice. Wallingford: CABI Publishing.
Rojek, C., Urry, J. (1997). Transformations of travel and theory. W: C. Rojek, J. Urry (red.), Touring cultures: transformations of travel and theory (s. 1-19). London: Routledge.

Stivers, E., Wheelan, S. (1986). The Lewin legacy: Field theory in current practice. Berlin-Heidelberg-Nowy Jork-Londyn-ParyżTokio: Springer-Verlag.

Strawiński, W. (2011). Funkcja i cele nauki - zarys problematyki metodologicznej. Zagadnienia Naukoznawstwa, 3 (189), 323-335.

Stumpf, T.S., Sandstrom, J., Swanger, N. (2016). Bridging the gap: Grounded theory method, theory, development and sustainable tourism research. Journal of Sustainable Tourism, 24 (12), 16911708. DOI: https://doi.org/10.1080/09669582.2016.1149183

Szulakiewicz, M. (2004). Filozofia jako hermeneutyka. Toruń: Wydawnictwo UMK.

Theuns, L. (1986). Priorytety w badaniach turystycznych. Przegląd opinii ekspertów, ze szczególnym uwzględnieniem krajów rozwijających się. Problemy Turystyki, 1, 48-66.

Tribe, J. (1997). The indiscipline of tourism. Annals of Tourism Research, 24 (3), 638-657. DOI: https://doi.org/10.1016/ S0160-7383(97)00020-0

Tribe, J. (2006). The truth about tourism. Annals of Tourism Research, 33 (2), 360-381. DOI: https:/ / doi.org/10.1016/j.annals. 2005.11.001

Tribe, J. (2010). Tribes, territories and networks in the tourism academy. Annals of Tourism Research, 37 (1), 7-33. DOI: https:// doi.org/10.1016/j.annals.2009.05.001

Tribe, J., Dann, G., Jamal, T. (2015). Paradigms in tourism research A trialogue. Tourism Recreation Research, 40 (1), 28-47. DOI https://doi.org/10.1080/02508281.2015.1008856

Tribe, J., Liburd, J.J. (2016). The tourism knowledge system. Annals of Tourism Research, 57, 44-61. DOI: https://doi.org/ 10.1016/j.annals.2015.11.011

Waszczyk, M. (1996). Wyjaśnianie i przewidywanie w bioelektronice. Roczniki Filozoficzne, XLIV (3), 145-176.

Waszczyk, M., Szczerbicki, E. (2003). Metodologiczne aspekty opisowego modelowania w naukach ekonomicznych. Zeszyty Naukowe Politechniki Gdańskiej - Filozofia, 7, 3-22.

Winiarski, R. (red.) (2003). Nauki o turystyce. Cz. I. Wyd. 2, poprawione i uzupełnione. Kraków: AWF Kraków.

Winiarski, R. (red.) (2004). Nauki o turystyce. Cz. II. Kraków: AWF Kraków.

Woleński, J. (1979). Wyjaśnianie a przewidywanie. Prace Naukoznawcze i Prognostyczne, 3 (24), 5-19.

Xiao, H., Smith, S. (2004). Source knowledge for tourism research. Annals of Tourism Research, 32 (1), 272-275. DOI: https:// doi.org/10.1016/j.annals.2004.06.004

Artykuł wpłynął 14 sierpnia $2019 \mathrm{r}$

Zaakceptowano do druku: 26 września $2019 \mathrm{r}$ 
